\title{
Impact of Physical Activity and Exercise on the Epigenome in Skeletal Muscle and Effects on Systemic Metabolism
}

\author{
Julio Plaza-Diaz ${ }^{1,2,3, * \mathbb{D}}$, David Izquierdo ${ }^{1,2}$, Álvaro Torres-Martos ${ }^{2} \mathbb{D}$, Aiman Tariq Baig ${ }^{3,4}(\mathbb{D}$,

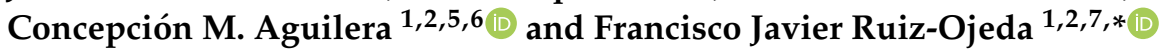

1 Department of Biochemistry and Molecular Biology II, School of Pharmacy, University of Granada, 18071 Granada, Spain; davidizquierdo@correo.ugr.es (D.I.); caguiler@ugr.es (C.M.A.)

2 Instituto de Investigación Biosanitaria IBS.GRANADA, Complejo Hospitalario Universitario de Granada, 18014 Granada, Spain; alvarotorresmartos@gmail.com

3 Children's Hospital of Eastern Ontario Research Institute, Ottawa, ON K1H 8L1, Canada; abaig034@uottawa.ca

4 Department of Cellular and Molecular Medicine, Faculty of Medicine, University of Ottawa, Ottawa, ON K1H 85M, Canada

5 Center of Biomedical Research, Institute of Nutrition and Food Technology "José Mataix", University of Granada, Avda. del Conocimiento s/n., 18016 Granada, Spain

6 CIBEROBN (CIBER Physiopathology of Obesity and Nutrition), Instituto de Salud Carlos III, 28029 Madrid, Spain

7 RG Adipocytes and Metabolism, Institute for Diabetes and Obesity, Helmholtz Diabetes Center at Helmholtz, Center Munich, Neuherberg, 85764 Munich, Germany

* Correspondence: jrplaza@ugr.es (J.P.-D.); fruizojeda@ugr.es (F.J.R.-O.); Tel.: +34-9-5824-1000 (ext. 20314) (F.J.R.-O.)

check for updates

Citation: Plaza-Diaz, J.; Izquierdo, D.; Torres-Martos, Á.; Baig, A.T.; Aguilera, C.M.; Ruiz-Ojeda, F.J. Impact of Physical Activity and Exercise on the Epigenome in Skeletal Muscle and Effects on Systemic Metabolism. Biomedicines 2022, 10, 126. https://doi.org/ 10.3390/biomedicines10010126

Academic Editor: Paola Ungaro

Received: 17 December 2021

Accepted: 4 January 2022

Published: 7 January 2022

Publisher's Note: MDPI stays neutral with regard to jurisdictional claims in published maps and institutional affiliations.

Copyright: (c) 2022 by the authors Licensee MDPI, Basel, Switzerland. This article is an open access article distributed under the terms and conditions of the Creative Commons Attribution (CC BY) license (https:// creativecommons.org/licenses/by/ $4.0 /)$.
Abstract: Exercise and physical activity induces physiological responses in organisms, and adaptations in skeletal muscle, which is beneficial for maintaining health and preventing and/or treating most chronic diseases. These adaptations are mainly instigated by transcriptional responses that ensue in reaction to each individual exercise, either resistance or endurance. Consequently, changes in key metabolic, regulatory, and myogenic genes in skeletal muscle occur as both an early and late response to exercise, and these epigenetic modifications, which are influenced by environmental and genetic factors, trigger those alterations in the transcriptional responses. DNA methylation and histone modifications are the most significant epigenetic changes described in gene transcription, linked to the skeletal muscle transcriptional response to exercise, and mediating the exercise adaptations. Nevertheless, other alterations in the epigenetics markers, such as epitranscriptomics, modifications mediated by miRNAs, and lactylation as a novel epigenetic modification, are emerging as key events for gene transcription. Here, we provide an overview and update of the impact of exercise on epigenetic modifications, including the well-described DNA methylations and histone modifications, and the emerging modifications in the skeletal muscle. In addition, we describe the effects of exercise on epigenetic markers in other metabolic tissues; also, we provide information about how systemic metabolism or its metabolites influence epigenetic modifications in the skeletal muscle.

Keywords: epigenetics; exercise; physical activity; skeletal muscle; metabolism

\section{Introduction}

Physical activity is defined as every physical action using skeletal muscles that produces an energy expenditure in daily time and can be classified into sports, occupational, household, conditioning, or other activities [1]. Exercise is a subsection of physical activity that is structured, premeditated, and cyclic and has as a final or an intermediate objective the progress or physical fitness maintenance related to both skills- or health-related aspects [2,3]. Physical activity and exercise are essential to maintain a healthy metabolism and burn more calories per day. In short, exercise is not just significant for general health, 
it is crucial to the molecular memory of who we are, simply because the lack of exercise increases the risk of obesity and type 2 diabetes, as well as developing diseases linked to brain function, such as dementia, psychiatric disorders, and even violent behavior [4,5]. Humans today may have a higher metabolic capacity than our ancestors did, measured by our capacity to take up and use oxygen $\left(\mathrm{VO}_{2} \mathrm{max}\right)$ [5]. A lack of exercise might have multiple, long-term damaging effects, in particular when coupled with a poor diet. Consequently, nowadays, the prevalence of chronic diseases associated with a sedentary lifestyle and poor diet has increased alarmingly [6].

Exercise is utilized to maintain or restore whole-body homeostasis and human locomotion, and it can cause several metabolic adaptations in the skeletal muscle in order to improve the performance of the body [7]. Therefore, a better understanding of the underlying mechanisms responsible for these adaptations will help to improve training guidelines [8]. Skeletal muscle is a plastic tissue capable of adapting rapidly in response to changes in metabolic homeostasis induced by exercise. In the physiology of exercise, two types of physical exercise are mainly differentiated: endurance training, which is characterized by using low and repeated loads, where the work of the cardiorespiratory system predominates; the term endurance training generally refers to training the aerobic system as opposed to the anaerobic system and strength or resistance training, which uses higher loads at low repetition exercise bouts and is focused more on working the neuromuscular system [9]. It also uses resistance to muscular contraction to build the strength, anaerobic endurance and size of skeletal muscles [10]. Most activities combine endurance and strength and this type of training has been termed concurrent exercise [11].

During exercise, both in endurance and resistance training, a series of acute responses occur in almost every system and tissue in the body. First, the motor cortex recruits the motor units of the target muscle to produce movement. Depending on the type of movement you want to achieve, different fibers will be activated. There are several types of fibers in our muscles; type I fibers are more resistant to fatigue and have a predominantly oxidative metabolism, whereas type IIx fibers are more glycolytic, fatigued and fast-twitch, and type IIa fibers are a combination of both [12]. The cardiovascular, respiratory, and hormonal systems and various metabolic processes are also activated in parallel, leading to a complete disruption of homeostasis [13]. The physiological responses prompt the activation of several kinases, including adenosine monophosphate (AMP)-activated protein kinase (AMPK), Protein kinase A (PKA), calcium/calmodulin-dependent protein kinase (CaMK), mitogen-activated protein kinase (MAPK), Protein kinase $C(P K C)$ and Mammalian target of rapamycin (mTOR) [14]. The energy-sensing kinase AMPK, which is regulated by cellular energy deficit $[15,16]$, plays an important role in the beneficial effects of exercise on whole-body metabolic homeostasis. Indeed, muscle-specific AMPK knockout mouse models exhibit a pivotal role for AMPK in the metabolic adaptation of muscle during exercise. Nonetheless, numerous reports have suggested the previously characterized metabolic disturbances induced with exercise are not completely dependent on AMPK.

Overall, AMPK activation through physical exercise improves mitochondrial biogenesis through the regulation of peroxisome proliferator-activated receptor gamma coactivator 1-alpha (PGC-1 $\alpha$ ), which promotes the expression of mitochondrial genes encoded in mitochondrial and nuclear DNA [17]. CaMK-II is another highly conserved studied protein, which is dependent on the intensity of exercise and whose activation promotes the activation of PGC-1 $\alpha$ and glucose transporter 4 (GLUT-4) [18]. Moreover, CaMK-II promotes lipid uptake and oxidation and skeletal muscle plasticity by disrupting members of myocyte Enhancer Factor 2 histone deacetylase (MEF2-HDAC) complexes and stimulating HDAC nuclear export; it also triggers regulation of important transcription factors, such as the cyclic AMP response element-binding protein (CREB), MEF2, and HDACs in skeletal muscle [19]. Finally, it is worth mentioning that there are several differences in molecular responses to exercise between endurance and resistance exercise. Generally, resistance training increases the activation of the phosphoinositide 3-kinases Protein kinase B-mTOR (PI3k-Akt-mTOR) signaling cascade to regulate the rate of protein synthesis and/or degra- 
dation and consequently, muscle hypertrophy. Nevertheless, endurance training activates the AMPK-MAPK-PGC- $1 \alpha$ signaling cascades, ultimately leading to increased mitochondrial biogenesis [13] and metabolic adaptations such as fast-to-slow muscle fiber transition, as well as angiogenesis.

In recent years, emerging evidence suggests that epigenetic modifications may mediate the intergenerational transmission of exercise effects on physiology. Epigenetics is a concept conceived by Conrad Waddington in 1940. Since then, the attention on this field has increased enormously, and herein, the definition of epigenetics has progressed toward changes in transcriptional expression and/or activity without variation in DNA sequence [20]. These changes are of vital importance in fundamental biology, regulating such processes as genomic imprinting and X chromosome inactivation, as well as being the most reliable molecular method of human biological age prediction, collectively underlying its importance and association with development, disease, and aging [21,22]. DNA methylation and histone modifications have been the most studied epigenetic events. Nevertheless, other potential epigenetic modifications such as those mediated by microRNAs (miRNAs) may alter gene expression via post-transcriptional modulation and may influence translational events. Furthermore, the identification of circulating miRNAs provided the possibility that they are involved in cell-cell and tissue-tissue communication [23]. Overall, the interactions between multiple epigenetic modifications and their regulation by metabolism during exercise are complex, and the comprehensive understanding of these adaptations needs to be further investigated.

In the present review, we provide an overview and update of the impact of exercise on the epigenome, including DNA methylation, histone modifications, miRNAs, epitranscriptomics, and novel mechanisms, such as lactylation in the skeletal muscle. In addition, we highlight the effect of exercise on epigenetic changes in other metabolic tissues such as adipose tissue, liver, pancreas, and brain, and we summarize the main effects of metabolism and its metabolites on epigenetic modifications in the skeletal muscle.

\section{Methods}

A comprehensive search of the relevant literature was performed in the electronic database MEDLINE through PubMed (U.S. National Library of Medicine and the NIH). The following phrases were included in the search of the literature without time restrictions: ((exercise[Title/Abstract]) OR (aerobic exercise[MeSH Terms]) OR (activity, physical[MeSH Terms])) AND (humans) AND ((epigenetic[MeSH Terms]) OR (epigenetic[Title/Abstract])) AND (muscle, skeletal[MeSH Terms]). In addition, in order to revise the evidence related to epigenetic and effects on systemic metabolism, we included the following phrases in the search: "epigenomics", "exercise", "muscle, skeletal", "DNA methylation", "histone code", "microRNAs", "adipose tissue", "liver", "pancreas" and "brain". Finally, previous original articles and reviews focusing on epigenetics and skeletal muscle in the context of exercise and physical activity were carefully examined.

\section{Physical Activity and Exercise and the Epigenetic Changes in Skeletal Muscle}

Epigenetics constitutes an important level of regulation in the expression of genes without changes in the DNA sequence [24]. The mechanisms involved in the regulation of gene expression are heritable, and the modifications that occur in the nucleotide sequence are reversible $[25,26]$. Each cell type possesses a distinct innate epigenetic signature or hallmark called the epigenome, which controls the conformation of the DNA strand in two distinct states, euchromatin and heterochromatin, by which access to the DNA of the transcription machinery is controlled [27]. It has been shown that epigenetic modifications can be influenced in a tissue-specific manner by environmental stimuli such as diet, smoking, or exercise [28]. In this context, epigenetic changes can be considered as the intersection between genetics and the environment (nature vs. nurture) [29]. Some epigenetic changes may play a key role in skeletal muscle, a malleable organ that responds to training sessions by inducing the expression of genes involved in structural, metabolic, and functional adap- 
tations leading to transient changes [30,31]. This suggests that epigenetic mechanisms are not only restricted to early developmental stages in humans, but also dynamic controllers of genomic plasticity in response to environmental factors [32]. Three major epigenetic modifications regulate gene expression, DNA methylation, histone modifications, and miRNA activity [31-33].

\subsection{Skeletal Muscle Physiology and Adaptations to Exercise}

The skeletal muscle is composed of $75 \%$ water, $20 \%$ protein, and $5 \%$ other compounds [34]. Total muscle mass depends on the balance between synthesis and degradation of proteins, which are processes sensitive to the nutritional state and hormonal balance of the individual, the physical activity or exercise performed, and the presence of any type of injury or disease $[35,36]$. The heterogeneity of skeletal muscle is a property of all muscles, which allows them to maintain their function in response to a wide range of demands [37]. Thus, the presence of fibers with different properties in the same muscle is the result of an adaptation to different activity patterns imposed by motor neurons, which allows the muscle to participate in activities with various metabolic and mechanical demands [38].

Skeletal muscle fibers are commonly classified as type I (slow contraction fiber, predominant oxidative metabolism, and fatigue resistance), type IIA (fast contraction fiber, predominant oxidative metabolism), and type IIx (a fiber that presents the fastest contraction pattern, with predominant glycolytic metabolism and a high degree of fatigue in sustained activities) [36]. During endurance exercise, large muscle groups are activated at an intensity that requires high efficiency in oxygen transport and release $[39,40]$. This process drives an increase in capillary supply to facilitate $\mathrm{O}_{2}$ uptake and transport, rising in the number and size of mitochondria, reinforcement of fat, and glycogen storage [41]. Furthermore, endurance exercise increases the concentration of oxidative enzymes of the Krebs cycle necessary for the aerobic production of ATP and facilitates greater development of the sarcoplasmic $\mathrm{Ca}^{2+}$ reticulum, deregulation of oxygen transport proteins, and improvement of metabolic capacity by increasing the synthesis of mitochondrial proteins without changes in the synthesis of myofibrillar proteins [36,42]. In contrast, resistance exercise increments the ability to generate force due in part to muscle hypertrophy that occurs as a result of the activation and fusion of satellite cells [43]. Moreover, higher myonuclei are produced and this results in increased protein synthesis and a number of myofilaments, myofibrils, and sarcomeres, increasing the individual muscle fibers' size $[9,44]$.

Several external factors influence muscle hypertrophy induced by resistance exercises, such as the intensity and load used during exercise or the availability of macronutrients, all interacting with the individual's genotype to determine muscle growth $[45,46]$. Muscle hypertrophy is the most recognized adaptation of resistance exercise, but other adaptations occur to support the biochemical, physical, and metabolic requirements of muscle growth [47]. The recognized hypertrophy results from complex intra- and extra-muscular communication to coordinate muscle growth [48]. Thus, a transient alteration occurs in the muscle after a training session, which results in a new stable state of the skeletal muscle [49]. Overall, skeletal muscle contraction during exercise raises force production and energy demand, with simultaneous activation of metabolic pathways and the physiological adaptation for oxygen and substrate supply, carbon dioxide and heat removal, fluid balance, and homeostatic regulation $[7,50]$.

\subsection{Epigenetics and Physical Activity/Exercise in Skeletal Muscle}

Existing knowledge of the molecular mechanisms involved in the adaptations conferred by exercise suggests that repeated and transient increases in the expression of exercise-responsive genes in skeletal muscle confer such adaptations over time, contributing to the positive effects of physical activity [51]. The regulator and adaptableness of biological processes involve post-synthesis chemical variation of three classes of fundamental macromolecules: DNA, RNA, and proteins. One of the most profuse variations is DNA methylation, which is extensive through all kingdoms of life and includes an alkylation 
reaction whereby a methyl group switches a hydrogen atom [27]. DNA methylation is one of the epigenetic mechanisms with the greatest influence on gene activity [52].

\subsubsection{DNA Methylation}

DNA methylation is one of the epigenetic mechanisms with the greatest influence on gene activity [52]. Vertebrate DNA can be covalently modified by methylation of cytosines present in the $5^{\prime} \mathrm{CpG}^{\prime}$ dinucleotide sequence. $\mathrm{CpG}$ is the abbreviation used to refer to the joining of the two nitrogenous bases, cytosine and guanine, separated by a phosphate that binds them to the DNA strand [53]. This process is catalyzed by a family of DNA methyltransferases (DNMT) that transfer a methyl group from S-adenyl methionine (SAM) to carbon 5 of the cytosine residue to form $5 \mathrm{mC}$ (5-methylcytosine) [54,55].

Most DNA methylation occurs on cytosines found in the known CpG as islands. The majority of gene promoters (approximately 70\%) reside in CpG islands [52]. These sequences are highly conserved, and their localization and conservation throughout evolution imply that they are functionally important regions. It appears that CpG islands have been conserved throughout evolution to promote gene expression by regulating chromatin structure and DNA binding of transcription factors [56,57].

DNMTs are enzymes that establish, recognize, and remove DNA methylation, they and are divided into three groups according to their function. DNMT writers that catalyze the addition of a methyl group to the cytosine residue (Dnmt1, Dnmt3a, and Dnmt3b); DNMT readers, which are enzymes that recognize the methyl group and bind to it to influence gene expression; DNA methyltransferases erasers, enzymes responsible for modifying and removing the $5 \mathrm{mC}$ methyl group to reverse DNA methylation $[52,58]$.

Commonly, DNA methylation results in the stable silencing of gene expression by repressing transcription [59]. Exercise generally results in DNA hypomethylation in key skeletal muscle genes, representing an early response that mediates skeletal muscle adaptations to exercise [41]. Thus, muscle contraction through physical exercise leads to adaptive responses that improve metabolic efficiency, oxidative capacity, and contractile activity by altering gene expression profiles and protein levels [60]. One hypothesis explaining how exercise triggers DNA methylation suggests that during muscle contraction several processes occur such as cytoplasmic $\mathrm{Ca}^{2+}$ release from, and subsequent reabsorption by, the sarcoplasmic reticulum and ATP consumption by myosin movement that alter the AMPATP ratio, 1 in AMPK activation [61]. There is also an increase in oxidative metabolism for the production of ATP necessary for muscle contraction [62]. This generates reactive oxygen species (ROS) that induce DNA to trigger a genomic response. ROS are modulated by members of carbon metabolism such as S-adenosyl methionine (SAM), which serve as donors of methyl groups used in DNA methylation [63]. Consequently, modulating the availability of methyl donors is how oxidative stress, along with calcium, could be the triggers that control exercise-induced methylation [32,64].

An example is found in the genes coding for the proinflammatory cytokines as interleukin 6 (IL-6) and tumor necrosis factor $\alpha$ (TNF- $\alpha)$. These are hypomethylated in skeletal muscle of sedentary people at rest when compared with people who practice strength training (sedentary people present greater expression of these genes so that their state of inflammation is greater) [65]. IL-6 protein levels normally increase when performing an intense exercise session, these levels are also higher in sedentary people than in people who practice exercise. This indicates a chronic adaptation in people who perform exercise that creates a methylation profile more prepared for recovery after physical activity by decreasing the basal expression of proinflammatory mediators [66].

PGC1- $\alpha$ is a key regulatory gene for mitochondrial biogenesis, fatty acid oxidation, and skeletal muscle sensitivity to insulin. The $P G C-1 \alpha$ gene is hypomethylated after an intense exercise session $[32,67,68]$. Barrès et al. performed biopsies of the vastus lateralis, in which they found a different methylation state of the promoter of this gene, specifically, $10 \%$ less methylated compared to the resting state. Hypomethylation levels of PCG-1 $\alpha$ correlate with increased mRNA levels three hours after endurance exercise, this affirms that 
changes in methylation are involved in the activation of transcription [60]. This gene and its control by epigenetic regulations are involved in numerous diseases and physiological conditions: regular sports practice in pregnant women prevents PGC- $1 \alpha$ hypermethylation induced by high-fat diets in offspring, and increases PGC- $1 \alpha$ levels, thereby ameliorating age-associated metabolic dysfunction. These data suggest that DNA methylation in PGC$1 \alpha$ may be related to metabolic memory in endurance exercise [69]. Moreover, 4 days of inactivity increases expression of genes in muscle associated with insulin resistance and increased DNA methylation in PGC-1 $\alpha$ in endurance exercise [70].

Training can alter the DNA methylation status of multiple genes in a dose-dependent manner. There is an indirect correlation between DNA methylation levels and the resulting levels of mRNA expression of several genes, but not all genes are studied in the skeletal muscle adaptive response to exercise $[31,60,67]$. In this context, changes in DNA methylation have been observed both immediately after an acute exercise session and chronically after a training program of several weeks or months. The magnitude of these changes is less after following a training program than after a single intense exercise session, indicating that changes in DNA methylation in response to exercise are a dynamic process that is activated early in gene expression. Nevertheless, residual changes in methylation are also maintained after the training stimulus disappears, indicating that they accumulate over multiple exercise sessions. In addition, it has been observed that the basal levels of methylation prior to the training program (levels typical of the untrained state) are not restored in the short term [31,32]. Therefore, several genes involved in the adaptive response of skeletal muscle to exercise have been studied in the published literature (Table 1).

TFAM (Mitochondrial Transcription Factor A) is a mitochondrial DNA (mtDNA) regulatory protein that protects from ROS and degradation while increasing mitochondrial function [71]. TFAM gene promoters are hypomethylated after just one exercise session and are maintained $3 \mathrm{~h}$ later. The mRNA levels also increased, but they do so immediately after the end of either endurance or resistance exercise [32,67]. The same occurs with peroxisome proliferator-activated receptor-gamma $(P P A R-\gamma)$ mRNA levels, but this gene shows delayed hypomethylation, indicating that DNA modifications may depend on exercise intensity (endurance or resistance) [31].

PDK4 (Pyruvate dehydrogenase kinase 4) is a key gene in skeletal muscle metabolism and its expression is associated with hyperglycemia and is increased after either highintensity exercise for a short period of time or after prolonged low-intensity exercise, and remains elevated as a consequence of chronic exercise. Its promoter is hypomethylated just after exercise, but transcription does not increase until $3 \mathrm{~h}$ later, as is the case with PGC-1 $\alpha$ in either endurance or resistance exercise [67]. The methylation levels of MEF2 (myocyte Specific Enhancer Factor 2) and CS (Citrate Synthase) decrease in response to exercise, but there are no significant changes in mRNA expression in endurance exercise [60]. 
Table 1. Effects of endurance and resistance training on DNA methylation in skeletal muscle.

\begin{tabular}{|c|c|c|c|c|c|c|c|}
\hline \multicolumn{8}{|c|}{ Endurance Exercise } \\
\hline Reference & $\begin{array}{l}\text { Sample } \\
\text { Size }\end{array}$ & Age and Sex & Participant Profiles & Exercise Doses & Biopsy Times & Technology & $\begin{array}{l}\text { Methylation Changes and } \\
\text { Gene Expression }\end{array}$ \\
\hline $\begin{array}{l}\text { Barres et al., } \\
\text { (2012) [60] }\end{array}$ & $\mathrm{n}=14$ & $\begin{array}{l}25 \pm 1 \text { years, men } \\
\text { and women }\end{array}$ & Sedentary & $\begin{array}{l}\text { Acute session, Intensity: } \\
80 \% \mathrm{VO}_{2} \text {, Volume: } \\
\text { until } 1.674 \mathrm{~kJ}\end{array}$ & $\begin{array}{l}\text { Before, after and } 3 \mathrm{~h} \\
\text { post-exercise }\end{array}$ & Pyrosequencing & $\begin{array}{l}\text { Hypomethylation of } P G C-1 \alpha \text {, } \\
\text { TFAM, MEF } 2 A Y P D K 4 \text { after } \\
\text { exercise. Hypomethylation of } \\
P P A R-d 3 \text { h post exercise }\end{array}$ \\
\hline $\begin{array}{l}\text { Bajpeyi et al., } \\
\text { (2017) [72] }\end{array}$ & $\mathrm{n}=11$ & $24 \pm 1$ years, men & $\begin{array}{l}\text { High and low } \\
\text { responders }\end{array}$ & $\begin{array}{l}\text { Acute session, Intensity: } \\
50 \% \mathrm{VO}_{2} \text {, Volume: } \\
\text { until } 650 \text { kcal }\end{array}$ & $\begin{array}{l}\text { Before and after } \\
\text { exercise }\end{array}$ & Pyrosequencing & $\begin{array}{c}\text { Hypomethylation of PGC1 } \alpha \text { and } \\
\text { higher mRNA levels in } \\
\text { responders to exercise }\end{array}$ \\
\hline $\begin{array}{l}\text { Lane et al., } \\
\text { (2015) [73] }\end{array}$ & $\mathrm{n}=7$ & $29 \pm 5$ years, men & $\begin{array}{l}\text { Cyclists completing } \\
\text { two trials receiving } \\
\text { isoenergetic diets } \\
\text { differing in the } \\
\text { timing of ingestion }\end{array}$ & $\begin{array}{l}\text { Acute session, Intensity: } \\
50 \% \mathrm{VO}_{2} \text {, Duration: } 120 \mathrm{~min}\end{array}$ & $\begin{array}{l}\text { Before and } \\
\text { after exercise }\end{array}$ & Pyrosequencing & $\begin{array}{l}\text { Hypermethylation of COX411 } \mathrm{y} \\
\text { FABP3 } 4 \mathrm{~h} \text { after the training } \\
\text { session. DNA methylation of } \\
\text { PPARs increased only in the } \\
\text { fasting group }\end{array}$ \\
\hline $\begin{array}{l}\text { Nitert et al., } \\
\text { (2012) [74] }\end{array}$ & $\mathrm{n}=28$ & $\begin{array}{l}37.5 \pm 5.2 \text { years } \\
\text { men }\end{array}$ & $\begin{array}{c}\text { Individuals } \\
\text { with/without } \\
\text { familiar diabetes } \\
\text { history }\end{array}$ & $\begin{array}{c}6 \text { months of endurance } \\
\text { exercise and spinning } \\
\text { (2-3 sessions per week, } 1 \mathrm{~h})\end{array}$ & $\begin{array}{l}\text { Before and } \\
\text { after exercise }\end{array}$ & MeDIP-Chip & $\begin{array}{l}\text { Hypomethylation of RUNX1, } \\
M E F 2 A, T H A D A \text { y NDUFC2 }\end{array}$ \\
\hline $\begin{array}{l}\text { Alibegovic et al., } \\
\text { (2010) [70] }\end{array}$ & $\mathrm{n}=20$ & $25 \pm 1$ years, men & $\begin{array}{l}\text { Healthy Caucasian } \\
\text { without Type } 2 \\
\text { diabetes antecedents }\end{array}$ & $\begin{array}{c}4 \text { weeks, } 6 \text { days per week, } \\
\text { Volume: } 30 \text { min, Intensity: } \\
70 \% \mathrm{VO}_{2} \max \end{array}$ & $\begin{array}{l}\text { Before and after } \\
\text { exercise }\end{array}$ & $\begin{array}{c}\text { EZ DNA } \\
\text { Methylation kit }\end{array}$ & $\begin{array}{l}\text { Hypermethylation of } \\
\text { PPARGC1A after } 8 \text { bed rest. } \\
\text { Hypomethylation of } \\
\text { PPARGC1A after a } \\
\text { training program }\end{array}$ \\
\hline $\begin{array}{l}\text { Robinson et al., } \\
\text { (2017) [75] }\end{array}$ & $\mathrm{n}=34$ & $\begin{array}{l}29 \pm 5 \text { years, men } \\
\text { and women }\end{array}$ & Adults & $\begin{array}{c}12 \text { weeks, } 3 \text { times per week, } \\
4 \times 4,90 \% \mathrm{VO}_{2}, 3 \text { min active } \\
\text { rest, } 3 \text { days of treadmill, } \\
\text { walking }(45 \mathrm{~min} 70 \%)\end{array}$ & $\begin{array}{l}\text { Before and } \\
\text { after exercise }\end{array}$ & $\begin{array}{l}450 \mathrm{~K} \text { array } \\
\text { (Illumina) }\end{array}$ & $\begin{array}{c}\text { Shifts in the DNA methylation } \\
\text { less than } 10 \%\end{array}$ \\
\hline $\begin{array}{l}\text { Lindholm et al., } \\
\text { (2014) [76] }\end{array}$ & $\mathrm{n}=23$ & $\begin{array}{l}27 \pm 0.8, \text { men } \\
\text { and women }\end{array}$ & $\begin{array}{c}\text { Young people } \\
\text { (without practicing } \\
\text { exercise) }\end{array}$ & $\begin{array}{c}3 \text { months (resistance to } 1 \mathrm{leg} \text { ) } \\
4 \text { sessions, } 45 \mathrm{~min}\end{array}$ & $\begin{array}{l}\text { Resting, before } \\
\text { and after }\end{array}$ & $\begin{array}{l}450 \mathrm{~K} \text { array } \\
\text { (Illumina) }\end{array}$ & $\begin{array}{l}\text { Changes in DNA methylation in } \\
5000 \text { sites and different gene } \\
\text { expression in } 4000 \text { genes. }\end{array}$ \\
\hline
\end{tabular}


Table 1. Cont.

\begin{tabular}{|c|c|c|c|c|c|c|c|}
\hline \multicolumn{8}{|c|}{ Endurance Exercise } \\
\hline Reference & Sample Size & Age and Sex & Participant Profiles & Exercise Doses & Biopsy Times & Technology & $\begin{array}{l}\text { Methylation Changes and } \\
\text { Gene Expression }\end{array}$ \\
\hline $\begin{array}{l}\text { Turner et al., } \\
(2020)[77]\end{array}$ & $\mathrm{n}=30$ & $27 \pm 4.4$ years, men & Young adults & $1-6$ sessions per week for 6 months & - & $\begin{array}{l}850 \mathrm{~K} \text { Array } \\
\text { (Illumina) }\end{array}$ & $\begin{array}{l}\text { Hypomethylation of HOXB1 y } \\
\text { HOXA3. }\end{array}$ \\
\hline $\begin{array}{l}\text { Sailani et al., } \\
\text { (2019) [78] }\end{array}$ & $\mathrm{n}=8$ & $\begin{array}{l}62.1 \pm 1.3 \text { years } \\
\text { men }\end{array}$ & $\begin{array}{l}\text { Healthy individuals, } \\
\text { (performing regular } \\
\text { exercise or remained } \\
\text { sedentary their } \\
\text { entire lives) }\end{array}$ & More than 3 times per week & - & $\begin{array}{l}850 \mathrm{~K} \text { Array } \\
\text { (Illumina) }\end{array}$ & $\begin{array}{l}\text { Hypomethylation in } 714 \text { promoters } \\
\text { of the physically active than inactive } \\
\text { men. Promoters for genes encoding } \\
\text { critical insulin-responsive enzymes } \\
\text { in glycogen metabolism, glycolysis } \\
\text { and TCA cycle were } \\
\text { hypomethylated in active relative to } \\
\text { inactive men. }\end{array}$ \\
\hline $\begin{array}{l}\text { Rowlands et al., } \\
\text { (2014) [79] }\end{array}$ & $\mathrm{n}=8$ & $\begin{array}{l}49 \pm 5 \text { years, Men } \\
\text { and women }\end{array}$ & $\begin{array}{l}\text { Individuals with type } \\
2 \text { diabetes and obesity }\end{array}$ & $\begin{array}{l}16 \text { weeks, } 3 \text { days per week, } \\
40-60 \text { min per session }\end{array}$ & Before and after exercise & $450 \mathrm{~K}$ array (Illumina) & $\begin{array}{l}\text { Hypermethylation in NRF1 y } \\
\text { SLC27A4 }\end{array}$ \\
\hline $\begin{array}{l}\text { Stephens et al., } \\
\text { (2018) [80] }\end{array}$ & $\mathrm{n}=17$ & $\begin{array}{l}50.7 \pm 1.9 \text { years } \\
\text { women }\end{array}$ & $\begin{array}{l}\text { Individuals with } \\
\text { type } 2 \text { diabetes }\end{array}$ & $\begin{array}{l}10 \text { weeks, } 4 \text { days per week, } \\
\text { Progressive intensity }\end{array}$ & Before and after exercise & $450 \mathrm{~K}$ array (Illumina) & $\begin{array}{l}\text { Hypermethylation in responders } \\
\text { compared to non-responders. }\end{array}$ \\
\hline $\begin{array}{l}\text { Maasar et al., } \\
(2021)[68]\end{array}$ & $\mathrm{n}=5$ & $26 \pm 2$ years, men & Sport team members & $\begin{array}{l}\text { (1) change of direction (COD) } \\
\text { versus; ( } 2 \text { ) straight line (ST), } \\
\text { running exercise. Wash-out period } \\
\text { of at least } 2 \text { weeks between trials. }\end{array}$ & $\begin{array}{l}\text { Before ( } 30 \mathrm{~min}) \text { and } 24 \mathrm{~h} \\
\text { after exercise }\end{array}$ & $\begin{array}{l}850 \mathrm{~K} \text { Array } \\
\text { (Illumina) }\end{array}$ & $\begin{array}{c}\text { Hypomethylation after } 30 \text { min, } \\
\text { mainly in } A M P K, M A P K, \text { protein } \\
\text { binding, insulin, and axon guidance } \\
\text { pathways. Hypermethylation of } \\
\text { VEGFA, PPARGC1A, NR4A3 }\end{array}$ \\
\hline \multicolumn{8}{|c|}{ Resistance Exercise } \\
\hline Reference & Sample Size & Age and Sex & Participants Profile & Exercise Doses & Biopsies Time & Technology & $\begin{array}{l}\text { Methylation Changes } \\
\text { and Gene Expression }\end{array}$ \\
\hline $\begin{array}{l}\text { Rowlands et al., } \\
\text { (2014) [79] }\end{array}$ & $\mathrm{n}=9$ & $\begin{array}{l}49 \pm 5 \text { years, men } \\
\text { and women }\end{array}$ & $\begin{array}{l}\text { Type } 2 \text { diabetes } \\
\text { and obesity }\end{array}$ & $\begin{array}{l}16 \text { weeks, } 3 \text { days per week, } \\
\text { Participants were randomized into } \\
\text { endurance or resistance exercise } \\
\text { groups comprising supervised } \\
\text { progressive-loading exercise } \\
\text { sessions } 3 \times / \text { week on } \\
\text { non-consecutive days }\end{array}$ & Before and after exercise & $\begin{array}{l}450 \mathrm{~K} \text { Array } \\
\text { (Illumina) }\end{array}$ & $\begin{array}{c}\text { Hypomethylation of } 409 \text { CpGs sites } \\
\text { and hypermethylation of } \\
146 \text { CpGs sites. }\end{array}$ \\
\hline
\end{tabular}


Table 1. Cont.

\begin{tabular}{|c|c|c|c|c|c|c|c|}
\hline \multicolumn{8}{|c|}{ Endurance Exercise } \\
\hline Reference & $\begin{array}{l}\text { Sample } \\
\text { Size }\end{array}$ & Age and Sex & Participant Profiles & Exercise Doses & Biopsy Times & Technology & $\begin{array}{l}\text { Methylation Changes and } \\
\text { Gene Expression }\end{array}$ \\
\hline $\begin{array}{l}\text { Seaborne et al., } \\
\quad(2018)[81]\end{array}$ & $\mathrm{n}=8$ & $\begin{array}{l}27.6 \pm 2.4 \text { years } \\
\text { men }\end{array}$ & Adults (non-trained) & $\begin{array}{l}\text { An acute bout of resistance } \\
\text { exercise (acute RE), followed by } \\
7 \text { weeks ( } 3 \mathrm{~d} / \text { week) of resistance } \\
\text { exercise (loading), } 7 \text { weeks of } \\
\text { exercise cessation (unloading) and } \\
\text { a further period of } 7 \text { weeks } \\
\text { ( } 3 \mathrm{~d} / \text { week) resistance } \\
\text { exercise (re-loading). }\end{array}$ & $\begin{array}{l}\text { Before the first training } \\
\text { session, after acute } \\
\text { exercise, after a period } \\
\text { of } 7 \text { weeks of resistance } \\
\text { exercise (loading), } \\
\text { exercise cessation } \\
\text { (unloading) and a } \\
\text { subsequent second } \\
\text { period of } 7 \text { weeks } \\
\text { resistance exercise } \\
\text { (reloading). }\end{array}$ & DNA microarray & $\begin{array}{c}\text { Hypomethylation of AXIN1, GRIK2, } \\
\text { CAMK-IV, TRAF1, UBR5, RPL35a, } \\
\text { HEG1, PLA2G16 y SETD3 }\end{array}$ \\
\hline $\begin{array}{l}\text { Bagley et al., } \\
(2020)[66]\end{array}$ & $\begin{array}{c}\mathrm{n}=11 \text { and } \\
\mathrm{n}=8\end{array}$ & $\begin{array}{l}26.2 \pm 0.1 \text { years, } \\
\text { and } 22.9 \pm 1.1 \text { years }\end{array}$ & $\begin{array}{l}\text { Trained vs sedentary } \\
\text { young individuals }\end{array}$ & $\begin{array}{c}3 \times 10 \text { repeats, } 70 \% \mathrm{RM} \text {, press and } \\
\text { leg extension }\end{array}$ & $\begin{array}{l}\text { Before and } 4 \mathrm{~h} \\
\text { after exercise }\end{array}$ & PCR & $\begin{array}{l}\text { Global DNA hypomethylation in } \\
\text { trained individuals compared to } \\
\text { sedentary. Hypermethylation of } \\
\text { GPAM y SREBF2 in trained } \\
\text { individuals and hypomethylation of } \\
\text { SREBF2 in sedentary individuals. } \\
\text { No changes in DNA methylation of } \\
\text { genes are associated with } \\
\text { hypertrophy and inflammation. }\end{array}$ \\
\hline & & \multicolumn{6}{|c|}{$\begin{array}{l}\text { Abbreviations. AMPK: AMP-activated protein kinase; AXIN1: CAMK-IV: calcium/calmodulin-dependent protein kinase type IV; GPAM: mitochondrial glycerol-3-phosphate } \\
\text { acyltransferase 1; GRIK2: Ionotropic glutamate kainate receptor type } 2 \text { subunit; HEG1: Cardiac development protein with EGF 1-like domains; HOXA3: HOXB1: MAPK: mitogen- } \\
\text { activated protein kinases; MEF2A: myocyte-specific enhancer factor 2a; NDUFC2: C2 subunit of NADH dehydrogenase; NR4A3: nuclear receptor 4A3; NRF1: nuclear respiratory factor 1; } \\
\text { PDK4: pyruvate dehydrogenase kinase 3; PGC-1 } \alpha \text { /PPARGC1A: peroxisome proliferator-activated receptor gamma 1-alpha coactivator; PLA2G16: PPAR: Peroxisomal Proliferator } \\
\text { Activated Receptors; RPL35a: RUNX1: redness-related transcription factor 1; SETD3: SET domain containing 3; SLC27A4: solute carrier family 27 member 4; SREBF2: sterol regulatory } \\
\text { element binding protein 2; TFAM: mitochondrial transcription factor A, THADA: TRAF1: TNF receptor associated factor 1; UBR5: E3 ubiquitin-protein ligase UBR5; THADA, associated } \\
\text { thyroid adenoma is a protein. }\end{array}$} \\
\hline
\end{tabular}


In a recent study, Figueiredo et al. (2021) revealed the impact of genetic and epigenetic mechanisms on skeletal muscle ribosome biogenesis in humans during both resistance and endurance exercise by evaluating the time-course of ribosome biogenesis and rRNA transcription regulatory factor responses. They showed that ribosome biogenesis and MYC transcription are associated principally with resistance but not endurance exercise, signifying preferential up-regulation during hypertrophic processes. With resistance exercise, ribosome biogenesis was associated with rDNA gene dosage, as well as epigenetic changes in enhancer and non-canonical MYC-associated areas in rDNA, but not the promoter. Overall, this study provides for the first-time new insights related to the regulation of ribosome biogenesis during exercise in humans. It seems that resistance exercise is more disposed to induce ribosome biogenesis than endurance exercise, and epigenetic mechanisms are critical regulators of this process [82,83]. In addition to that, they found that endurance exercise increases AMPK phosphorylation at the Thr172 site after $30 \mathrm{~min}$ of exercise in skeletal muscle biopsies from vastus lateralis. Furthermore, they showed that resistance exercise activated $\mathrm{mTORC} 1$ signaling by increasing the ribosomal protein S6 kinase (p70S6K) at Thr389 and ribosomal protein S6 (rpS6) at Ser240/244, confirming previous results observed in the literature [84].

A recent study revealed that resistance exercise training affects mtDNA methylation patterns in skeletal muscle, as 63\% (159/254) of the GpG sites demonstrated reduced methylation. Some of the mtDNA sites presented a more "youthful" signature in older males after resistance training compared to younger males. Furthermore, enhanced expression of mitochondrial H-and L-strand genes and complex III/IV protein levels were also observed in this study [85].

\subsubsection{Histone Modifications}

Histones contain two domains, a central region (long alpha-helix flanked by two short alpha-helices) folded and interacting with DNA, and an N-terminal domain of 15-30 residues called "histone tails". These histone tails emerge from the central region of the nucleosome and undergo various post-translational modifications that affect chromatin structure and function. Epigenetic modifications are responsible for transforming the packaging of DNA and whether or not it can be utilized [86].

The most important histone post-translational modifications are acetylation, methylation, and phosphorylation. This wide variety of modifications and the combination among them provides a great potential for functional responses since they are dynamic changes that vary rapidly in response to cellular stimuli [87].

The "histone code" is the set of modifications undergone by histones and read by effector proteins that initiate biological responses such as activation or repression of transcription [88-90]. Some modifications are associated with activation and others with gene repression, although the effects seem to depend on the context in which they occur. DNA in euchromatin has greater functional flexibility, genes can be activated or remain inactive, and DNA can be unpacked for replication or repair. Transcriptionally active euchromatin has high levels of acetylation while transcriptionally inactive heterochromatin has low levels of acetylation, phosphorylation, and methylation [91,92]. On the other hand, inactive heterochromatin is associated with low levels of acetylation and high levels of methylation of some histone residues [93].

Exercise has a profound effect on the distribution of the histone markers. Many studies have found increased levels of methylation in H3K4 (histone H3 lysine 4), acetylation in H3K27 (histone H3 lysine 27), and phosphorylation in serine in H3 in skeletal muscle. The levels of the H3K27ac mark are a prominent marker of enhancer activity after 6 weeks of endurance training (Table 2) [94]. 
Table 2. Effects of endurance and resistance training on histone modification in skeletal muscle.

\begin{tabular}{|c|c|c|c|c|c|c|c|}
\hline \multicolumn{8}{|c|}{ Resistance and Endurance Exercise } \\
\hline Reference & $\begin{array}{l}\text { Sample } \\
\text { Size }\end{array}$ & Age and Sex & $\begin{array}{c}\text { Participant } \\
\text { Profiles }\end{array}$ & Exercise Doses & Biopsy Times & Technology & $\begin{array}{c}\text { Epigenetic Changes } \\
\text { and Gene } \\
\text { Expression }\end{array}$ \\
\hline $\begin{array}{l}\text { McGee et al., } \\
\text { (2009) [95] }\end{array}$ & $\mathrm{n}=9$ & $\begin{array}{l}23 \pm 1 \text { years } \\
\text { men }\end{array}$ & Healthy adults & $\begin{array}{c}\text { Volume: } 60 \mathrm{~min}, \\
72 \pm 2 \% \\
\mathrm{VO}_{2} \max \end{array}$ & $\begin{array}{l}\text { Before and } \\
\text { after exercise }\end{array}$ & Electrotransference & $\begin{array}{l}\text { Higher global } \\
\text { acetylation of H3K36 }\end{array}$ \\
\hline $\begin{array}{l}\text { Yu et al., } \\
\text { (2003) [96] }\end{array}$ & $\mathrm{n}=9$ & $\begin{array}{l}27 \pm 2 \text { years } \\
\text { men }\end{array}$ & $\begin{array}{l}\text { Trained and } \\
\text { non-trained } \\
\text { individuals }\end{array}$ & $\begin{array}{l}\text { Intensity: } \\
85 \% \mathrm{VO}_{2} \text { max, } \\
\text { Rest: } 60 \mathrm{~s}\end{array}$ & $\begin{array}{c}\text { Before and } \\
\text { after exercise }\end{array}$ & Electrotransference & $\begin{array}{c}\text { Higher } \\
\text { phosphorylation of } \\
\text { H3Histones }\end{array}$ \\
\hline
\end{tabular}

Acetylation

Histone acetylation is a transient enzymatic process that is the most common histone post-translational modification. The acetyl group of acetyl-CoA is transferred to a lysine residue of the histone tails [97]. Changes in the positive charges generated a DNA molecule more exposed and accessible to regulatory proteins and associating acetylation with gene activation [98-100].

DNA acetylation is mediated by histone acetyltransferases (HATs) that add an acetyl group to the histone, and histone deacetylases (HDACs) that remove it. The relative levels of histone acetylation are determined by the opposing enzymatic activities of HATs and HDACs [33]. Exercise is associated with the acetylation of several lysine residues in human skeletal muscle histones, so that physical activity correlates with chromatin decompaction and activation of transcription of certain exercise-responsive genes [101,102]. The practice of intense strength exercise produces an increase in histone H3 acetylation [103].

\section{Methylation}

Methylation takes place at the lysine and arginine residues of histones $\mathrm{H} 3$ and $\mathrm{H} 4$, to which a methyl group is added [104]. Histone methyltransferases (HMT) are responsible for catalyzing this reaction, using SAM as a substrate to transfer a methyl group to the lysines [105]. Methylated lysines and arginines can activate or repress gene transcription depending on the proteins they recruit to chromatin [97].

Lysines can be mono-, di-, or trimethylated (me1, me2, and me3 respectively) which will result in different responses. In general, methylation of H3K4, H3K36, and H3K79 is associated with epigenetic marks that activate gene transcription, whereas methylation of $\mathrm{H} 3 \mathrm{~K} 9, \mathrm{H} 3 \mathrm{~K} 27$, and $\mathrm{H} 4 \mathrm{~K} 20$ is associated with chromatin condensation and repression of gene expression [106]. H3K4 methylation is highly abundant in promoter regions and transcriptional start sites and increases with physical exercise [107].

\section{Phosphorylation}

Phosphorylation occurs at the serine and tyrosine residues of histones [108]. Exercise causes increased levels of $\mathrm{H} 3$ serine phosphorylation in skeletal muscle [96]. Thus, certain signaling pathways including AMPK, MAPK, PKA, PKC, and CaMK-II are important for phosphorylation-dependent signaling during exercise in skeletal muscle [14].

Many studies relate these pathways to histone modifications. Both AMPK and CaMKII directly phosphorylate H3 [109,110]. The available theory suggests that H3 phosphorylation is necessary prior to acetylation, i.e., there is a step-by-step control of chromatin decompaction and mechanisms necessary for the initiation of transcription [111].

\section{Lactylation}

Lactate is a cell marker of metabolic state, which results in epigenetics and transcriptomics changes in the cell. Furthermore, lactate inhibits the HDAC activity and thus increases gene expression boosting lactate availability during exercise [112].

Lysine lactylation is an epigenetic modification that occurs in the presence of elevated levels of lactate [113]. During exercise, lactylation appears in promoters of coding genes; 
this epigenetic code is associated with changes in transcriptional patterns [22]. Some authors have found evidence that lactylation mechanisms are based on Lactyl-CoA, an epigenetic "writer" in macrophage cell models. Moreover, they discovered that lysine lactylation is involved in the up-regulation of homeostatic genes. It is suggested that lactate and lactylation could play a communication role between cells and tissue inducing adaptive responses during and after exercise [114]. However, the mechanisms and metabolic implications of lactylation in skeletal muscle remain unclear and for that, future in-depth research on lactylation would be necessary.

\subsubsection{Micro-RNAs}

Micro-RNAs are small non-coding RNAs that generally repress the expression of several genes (from one hundred to a thousand) at a post-transcriptional level. The presence of micro-RNAs is usually due to non-homeostatic conditions and for that reason, they are relevant in the study of exercise physiology [30]. Micro-RNAs arising from skeletal or cardiac muscle are called myomiRs. Currently, only seven myomiRs related to skeletal muscle have been identified: miR-1, miR-133a, miR-133b, miR-206 (expressed only in skeletal muscle), miR-208b, miR-486, and miR-499, and their expression levels depend on the type and length of the exercise [31]. In general, the myomiRs' functions are to control the biogenesis, regeneration, and maintenance of the skeletal muscle tissue [115]. The evidence suggests that exercise increases the expression of proteins, which are implicated in micro-RNAs maturation, for example, Drosha, Dicer, and Exportin-5, and raises expression levels of myomiRs. For that reason, it can be assumed that exercise and micro-RNAs have a much-linked relationship [116].

MyomiRs control several post-training processes regulating the expression of different genes. Firstly, miR-133a promotes the myoblast proliferation; secondly, miR-1, miR133a, miR133b, miR-206, and miR-486 stimulate the myoblast differentiation (miR-1 and miR-206 down-regulate HDAC4). Then, miR-133a, miR-133b, and mir486 result in muscle cell fusion, and lastly, miR-1, miR-133a, and miR-206 encourage muscle regeneration. In addition, myomiRs are involved in other processes such as muscle fiber shift and muscle growth, as in the case of miR-133a, miR-208b, and miR-499 [117]. It is worth pointing out that miR-1 and miR-206 have been proposed as biomarkers of endurance [118]. Table 3 summarize the effects of endurance and resistance exercise on mi-RNAs generation in skeletal muscle.

Mainly, one unique micro-RNA can interact with many target mRNAs and one unique mRNA can interact with several micro-RNAs at the same time. This fact makes it difficult to understand molecular pathways in which micro-RNAs are implicated [115]. Some authors have tried to provide more complete information about the myomiRs' and other micro-RNAs' implications in these complex pathways related to myogenesis and muscle-skeletal differentiation.

\subsubsection{Epitranscriptomics}

In the past, RNA modifications were considered irreversible, and it was believed their function was to give structural stability and catalytic functions. When it was discovered that RNA modifications are reversible, epitranscriptomics began to emerge as a field. Recent studies have provided more information about the location and abundance of RNA modifications. These studies have declared N6-methyladenosine (m6A) as one of the most important RNA modifications. 
Table 3. Effects of endurance and resistance training on mi-RNAs generation in skeletal muscle.

\begin{tabular}{|c|c|c|c|c|c|c|c|}
\hline \multicolumn{8}{|c|}{ Endurance Exercise } \\
\hline Reference & Sample Size & Age and Sex & Participant Profiles & Exercise Doses & Biopsy Times & Technology & $\begin{array}{l}\text { Epigenetic Changes and } \\
\text { Gene Expression }\end{array}$ \\
\hline $\begin{array}{l}\text { Russel et al., } \\
\text { (2013) [116] }\end{array}$ & $\mathrm{n}=9$ & $23 \pm 5$ years, men & $\begin{array}{c}\text { Healthy people (less } \\
\text { than } 2 \mathrm{~h} \text { of exercise } \\
\text { per week) }\end{array}$ & $\begin{array}{c}\text { Acute: } 60 \mathrm{~min} \\
70 \% \mathrm{VO}_{2} \max , \\
\text { Chronic (10 days), } \\
\text { Progression: from } 45 \\
\text { a } 90 \text { min to } 75 \% \mathrm{VO}_{2}, \\
4 \text { days of } \mathrm{HIIT}: \\
6 \times 5 \mathrm{~min} \\
\left(90-100 \% \mathrm{VO}_{2}\right) \\
2 \text { min of resting }\end{array}$ & $\begin{array}{l}\text { Before and after } \\
\text { intervention }\end{array}$ & TaqMan qRT-PCR & $\begin{array}{c}\text { Acute: up-regulation of } \\
\text { miR-1, }-133 a, 133 b,-181 \\
\text { and down-regulation of } \\
\text { miR-9, }-23 a,-23 b, y-31 \text {. } \\
\text { Chronic: up-regulation of } \\
\text { miR-29b and } \\
\text { down-regulation of miR-31 }\end{array}$ \\
\hline $\begin{array}{l}\text { Keller et al., } \\
\text { (2011) [119] }\end{array}$ & $\mathrm{n}=8$ & $29 \pm 6$ years, men & $\begin{array}{l}\text { Sedentary healthy } \\
\text { individuals }\end{array}$ & $\begin{array}{c}4 \text { days/week, } \\
70 \% \mathrm{VO}_{2} \max , 45 \min \end{array}$ & $\begin{array}{l}\text { Before and after } \\
\text { intervention }\end{array}$ & TaqMan RT-PCR & $\begin{array}{l}\text { Lower expression of } \\
\text { miRNAs (14 vs } 7), \text { Lower } \\
\text { levels of miR-1, miR-133, } \\
\text { miR-101 y miR- } 455 \text {. }\end{array}$ \\
\hline $\begin{array}{l}\text { Nielsen et al., } \\
\text { (2010) [120] }\end{array}$ & $\mathrm{n}=10$ & $30.5 \pm 5.5$ years & Trained individuals & $\begin{array}{l}\text { Acute: } 60 \text { min, } 65 \% \\
\text { Pmax, Chronic } \\
\text { (12 weeks), } 5 \text { days } \\
\text { per week, } 55-91 \% \\
\text { Pmax, } 60-150 \text { min }\end{array}$ & $\begin{array}{l}\text { Before, } 1 \mathrm{~h} \text { before and } 3 \mathrm{~h} \\
\text { after intervention }\end{array}$ & TaqMan RT-PCR & $\begin{array}{l}\text { Acute: Higher expression } \\
\text { of miR-1 and }-133 a, \\
\text { Chronic: all miRNAs were } \\
\text { lower and restored after } \\
2 \text { weeks of intervention }\end{array}$ \\
\hline $\begin{array}{l}\text { Fyfe, J.J. et al., } \\
(2016)[121]\end{array}$ & $\mathrm{n}=8$ & $27 \pm 4$ years, Men & $\begin{array}{l}\text { Active young } \\
\text { individuals }\end{array}$ & $\begin{array}{l}2 \times 10 \mathrm{~min}, 1 \mathrm{~min} \\
\text { rest, } 120 \% \text { lactic } \\
\text { umbral }\end{array}$ & $\begin{array}{l}\text { Before, } 1 \mathrm{~h} \text { before and } 3 \mathrm{~h} \\
\text { after intervention }\end{array}$ & TaqMan RT-PCR & $\begin{array}{l}\text { Lower expression of } \\
\text { miR-133a, miR-378 y } \\
\text { miR-486 }\end{array}$ \\
\hline $\begin{array}{l}\text { Margolis, L.M. } \\
\text { et al., } 2017 \text { [122] }\end{array}$ & $\mathrm{n}=25$ & $\begin{array}{l}\text { 18-40 years, Men } \\
\text { and women }\end{array}$ & & $\begin{array}{c}90 \mathrm{~min}, \\
2.2 \pm 0.1 \mathrm{~L} / \mathrm{min}\end{array}$ & $\begin{array}{l}\text { Before and } 3 \mathrm{~h} \text { after } \\
\text { intervention }\end{array}$ & TaqMan RT-PCR & $\begin{array}{l}\text { Lower expression of } \\
\text { myomiR in the highest } \\
\text { loaded group (miR-1-3p, } \\
\text { miR-206, miR-208a-5p, } \\
\text { y miR-499), Higher } \\
\text { expression of myomiR in } \\
\text { the endurance group }\end{array}$ \\
\hline
\end{tabular}


Table 3. Cont.

\begin{tabular}{|c|c|c|c|c|c|c|c|}
\hline \multicolumn{8}{|c|}{ Resistance Exercise } \\
\hline Reference & Sample Size & Age and Sex & Participants Profile & Exercise Doses & Biopsies Time & Technology & $\begin{array}{l}\text { Epigenetic Changes and } \\
\text { Gene Expression }\end{array}$ \\
\hline $\begin{array}{l}\text { Davidsen et al., } \\
\text { (2011) [123] }\end{array}$ & $\mathrm{n}=56$ & 18-30 years, men & Active individuals & $\begin{array}{c}12 \text { weeks } \\
5 \text { days/week } \\
60 \text { min per session } \\
20 \text { sets by } \\
\text { muscle group }\end{array}$ & $\begin{array}{c}\text { Before and } \\
\text { after intervention }\end{array}$ & TaqMan RT-PCR & $\begin{array}{c}17 \text { miRNAs were detected, } \\
\text { and miR-78, miR-29a, } \\
\text { miR-26a, and miR-451 } \\
\text { were lower in the } \\
\text { low-responders. miR-451 } \\
\text { was up-regulated. }\end{array}$ \\
\hline $\begin{array}{l}\text { Rivas et al., } \\
\text { (2014) [124] }\end{array}$ & $\mathrm{n}=8$ & $\begin{array}{c}22 \pm 1 \text { years, } \\
74 \pm 2 \text { years, men }\end{array}$ & $\begin{array}{l}\text { Adults, Young and } \\
\text { old people }\end{array}$ & $\begin{array}{c}3 \text { series of } \\
10 \text { repetitions, } 80 \% \\
\text { Maximun repetition, } \\
2 \text { types of exercises }\end{array}$ & $\begin{array}{l}\text { Before and } 6 \mathrm{~h} \\
\text { after intervention }\end{array}$ & PCR-Array & $\begin{array}{c}17 \text { miRNAs were } \\
\text { differentially expressed in } \\
\text { young people and no } \\
\text { changes were found in old } \\
\text { individuals. Only } \\
\text { miR-423-5p was } \\
\text { up-regulated in both } \\
\text { young and old individuals. }\end{array}$ \\
\hline $\begin{array}{l}\text { Ogasawara et al., } \\
\text { (2016) [125] }\end{array}$ & $\mathrm{n}=18$ & $21.4 \pm 1.1$ years, men & $\begin{array}{l}\text { Healthy and } \\
\text { trained (resistance) } \\
\text { individuals }\end{array}$ & $\begin{array}{c}12 \text { weeks: } \\
10 \text { repetitions at } 70 \% \\
\text { of } 1 \text { repetition } \\
\text { maximum }(\mathrm{RM}) \text { for } \\
3 \text { sets with } 2 \text { min } \\
\text { rest intervals. } \\
3 \text { days per week on } \\
\text { alternative days for } \\
6 \text { week. }\end{array}$ & $\begin{array}{l}\text { Before and } 3 \mathrm{~h} \\
\text { after intervention, } \\
12 \text { weeks after }\end{array}$ & $\begin{array}{c}\text { Multiplexed } \\
\text { NanoString nCounter } \\
\text { human miRNA } \\
\text { expression assay }\end{array}$ & $\begin{array}{c}26 \text { miRNAs were different } \\
\text { between high and } \\
\text { low responders, } \\
\text { miRNA-136-5p and } \\
\text { miRNA-376a-3p were } \\
\text { up-regulated both in the } \\
\text { acute and } \\
\text { chronic treatment }\end{array}$ \\
\hline $\begin{array}{l}\text { Mueller et al., } \\
\text { (2011) [126] }\end{array}$ & $\mathrm{n}=28$ & $\begin{array}{c}80.1 \pm 3.7 \text { years, men } \\
\text { and women }\end{array}$ & Old individuals & $\begin{array}{l}2 \text { sessions per week } \\
\text { for } 12 \text { weeks of } \\
\text { training with two } \\
\text { weekly resistance } \\
\text { exercise sessions or } \\
\text { eccentric ergometer } \\
\text { sessions }\end{array}$ & $\begin{array}{l}\text { Before and } 12 \text { weeks } \\
\text { after intervention }\end{array}$ & $\begin{array}{l}\text { miRNA analysis by } \\
\text { custom-designed } \\
\text { low-density } \\
\text { PCR arrays }\end{array}$ & $\begin{array}{l}\text { Lower expression of } \\
\text { miRNA } 1\end{array}$ \\
\hline
\end{tabular}


Literature suggests that $\mathrm{m} 6 \mathrm{~A}$ is mainly located in the start and stop codons $/ 3^{\prime}$ untranslated regions ( $\left.3^{\prime} \mathrm{UTR}\right)$. Moreover, other RNA modifications have been described such as pseudouridine ( $\Psi)$, N1-methyladenosine (m1A), N6,2'-O- dimethyladenosine $(\mathrm{m} 6 \mathrm{Am}), 5$-methylcytosine $(\mathrm{m} 5 \mathrm{C})$ and 5-hydroxymethylcytosine $(\mathrm{hm} 5 \mathrm{C})$, and inosine. Several authors have described other RNA modifications, but they cannot be detected by the current methods. In addition, enzymes or enzymatic complexes which are able to catalyze and remove these RNA modifications (mainly, methyltransferases and demethylases), known as "writers" and "erasers" respectively, remain undisclosed in the majority of cases. One specific role is that of binding proteins, which are able to recognize RNA modification and induct molecular changes; these proteins are called "readers" [127].

This review has been focused on a known "writer" of m6A in mammalians, methyltransferase 3 (METTL3), which likely plays a relevant role in altering the micro-RNAs' expression during and after exercise. It is known that METTL3 catalyzes the maturation of micro-RNAs producing an m6A modification in primary micro-RNAs. In skeletal muscle, METTL3 can down-regulate the expression of miR-1, miR-133a, miR-133b, and miR-206; in other words, METTL3 and myomiRs are involved in antagonist functions [128]. For that reason, it is very relevant to know the dynamics of METTL3 and myomiRs deeply. It has been described that after a muscle injury the expression of METTL3 increases, promoting muscle regeneration. Nonetheless, when the muscle cell repair is done, the expression levels of METTL3 decrease, facilitating muscle differentiation [129]. Additionally, METTL3 could play a critical role in skeletal muscle differentiation and regeneration processes according to recent studies. They have demonstrated that after a muscle injury METTL3 and methyltransferase 14 (METTL14), which form a "writer" enzymatic complex, up-regulate the expression of MAPK Interacting Serine/Threonine Kinase 2 (MNK2) through m6A modification to post-transcriptional level. These molecular events could enhance the regeneration and proliferation of the skeletal muscle. The previous modification is mediated by YTH N6-Methyladenosine RNA Binding Protein 1 (YTHDF1), suggesting that it could be a probable "reader". Consequently, the levels of METTL3/14 and MNK2 decrease, facilitating the differentiation process. The evidence could indicate that MNK2 is an inhibitor of the ERK/MAPK signaling pathway being an essential molecular mechanism in the previously mentioned processes. It is also interesting to mention FTO Alpha-Ketoglutarate Dependent Dioxygenase (FTO) as a known "eraser" of m6A in skeletal muscle (Figure 1). These facts suggest that METTL3/14 could play a key role in controlling the micro-RNAs and other RNA/protein factors activity in the post-training process through m6A modification $[129,130]$. However, these conclusions should be validated in human cell models because the findings are in mouse cell models, in particular C2C12 cells $[129,130]$. 


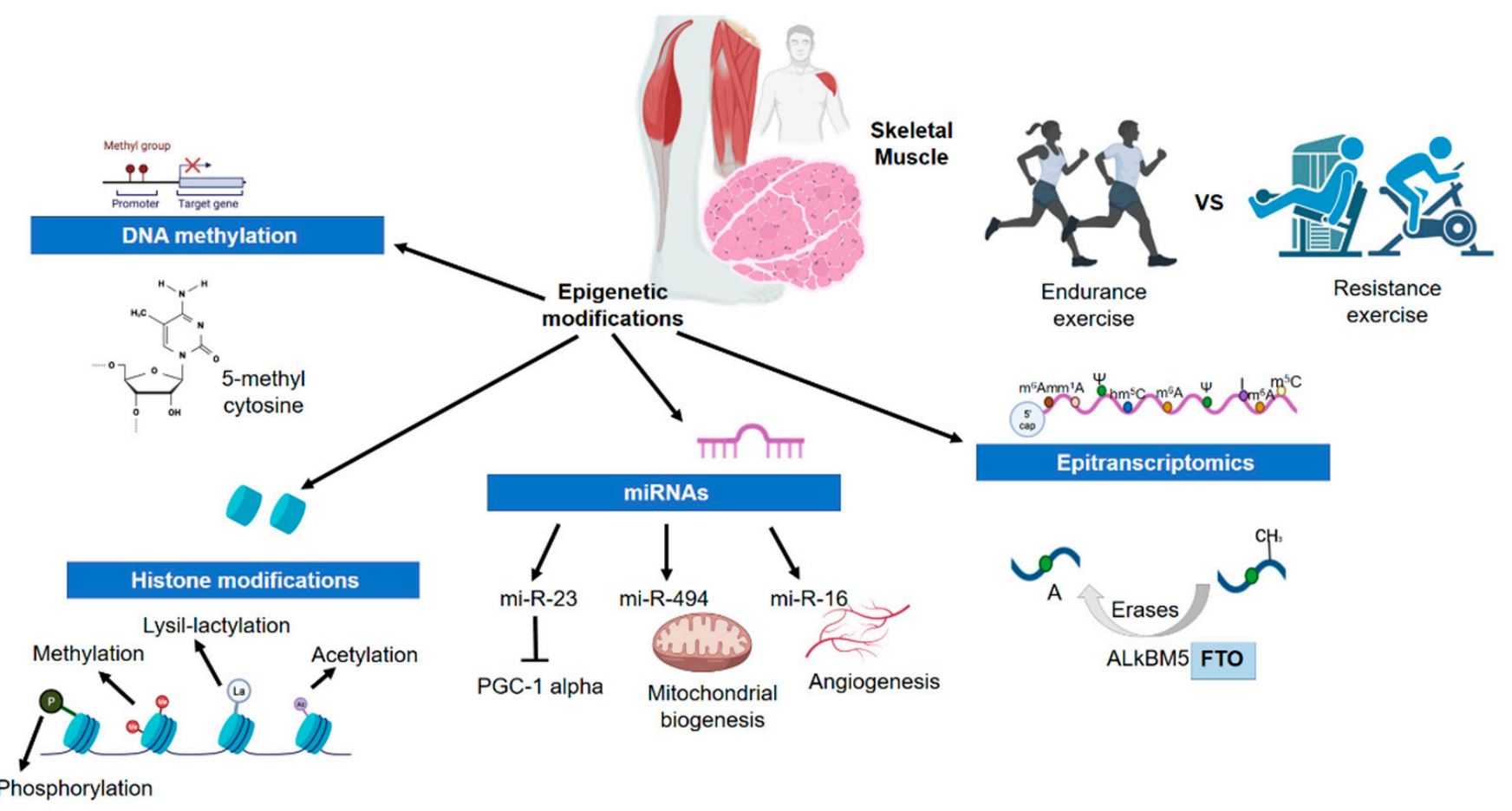

Figure 1. Effects of exercise on epigenetic modifications in skeletal muscle. Abbreviations: FTO, alphaKetoglutarate dependent dioxygenase; PGC-1 alpha, Peroxisome Proliferator-Activated Receptor Gamma Coactivator 1 Alpha.

\section{Epigenetics Mechanisms in Other Non-Muscle Tissue during Exercise}

Nowadays, epigenetic changes have become a cause of great interest since it has been shown that external variables, including physical activity and diet, could change the epigenome [131,132]. Transcriptional adaptive responses to exercise happen in several tissues [133]. Previous reports have mentioned that some gene expression alterations after running were observed deeper in the liver than in skeletal muscle in mice [134]. Modifications of histones were reported in several brain regions in response to forced swimming in rats and mice, inducing H3K14 acetylation and serine 10 phosphorylation in spatially distinct regions of the dentate gyrus in a time-dependent manner [135]. Moreover, exercised rats have shown augmented $\mathrm{H} 3$ acetylation at the brain-derived neurotrophic factor (BDNF) promoter in the hippocampus [136]. Thus, epigenetic mechanisms are present in other non-muscle tissues during physical activity or exercise (Figure 2).

\subsection{Adipose Tissue}

In chromatin immunoprecipitation assays on human multipotent adipose-derived stem cells, more bindings were identified on ELOVL fatty acid elongase 6 functional carbohydrate action [137] than on positive control regions in retinoid-related orphan receptor gamma and thioredoxin-interacting protein, a well-described target of carbohydrateresponsive element-binding protein [138]. Targeting the hormone-sensitive lipase-glucoseresponsive transcription factor (ChREBP) interaction may allow therapeutic strategies for the restoration of insulin sensitivity [138].

Adipose altered gene expression in genes associated with carbohydrate metabolism and glucose transport, including glucose transporter (GLUT)-4 has been reported in mice after exercise [139]. Epigenetic analyses have revealed that histone 4 acetylation regulation might be altered on the visceral adipose transcriptome [140]. In particular, histone deacetylase 5 (HDAC5) is implicated as an important mediator of changes in Glut4 mRNA levels in response to exercise in mice visceral adipose tissue. 


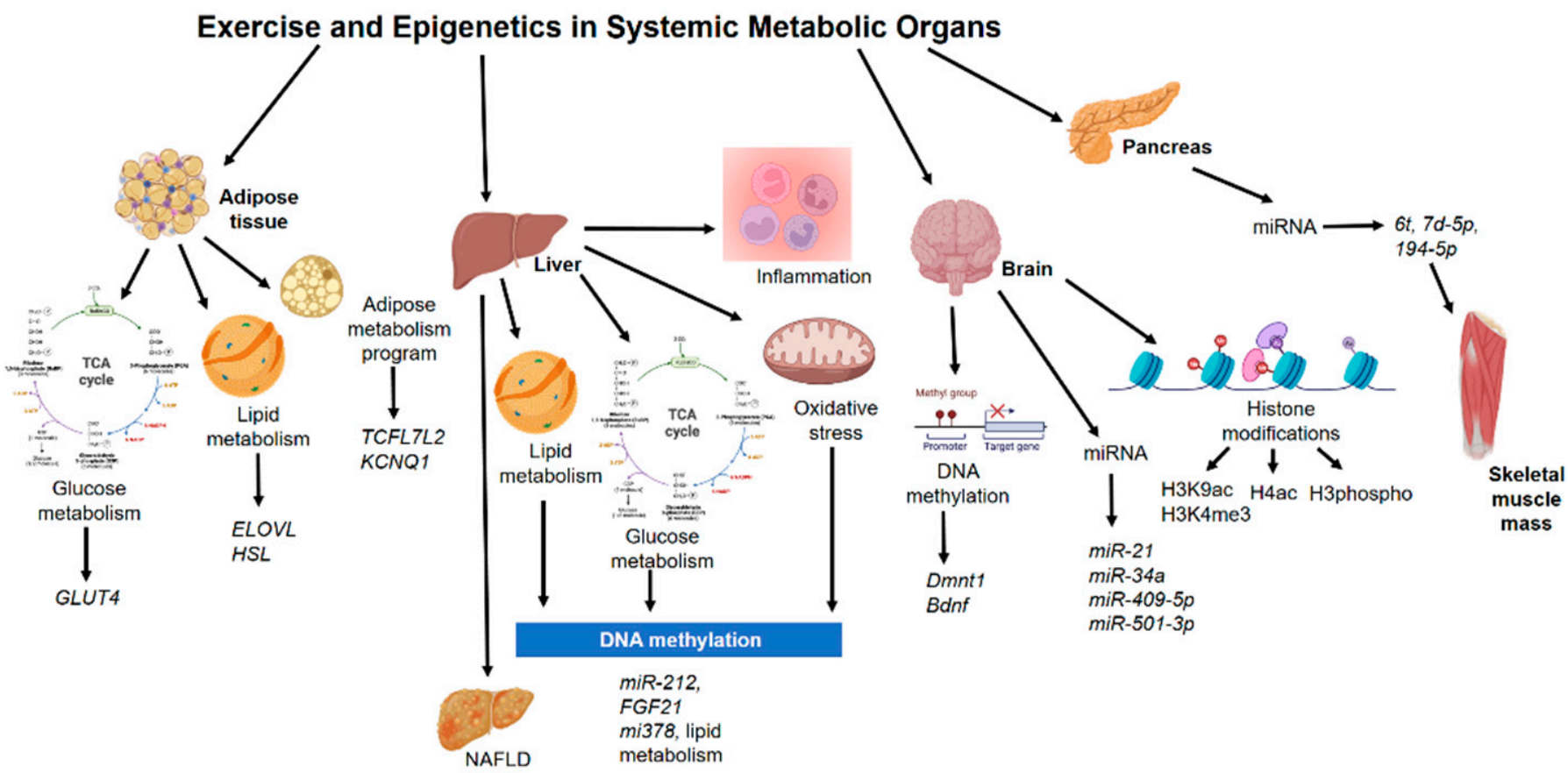

Figure 2. Epigenetics mechanisms in other non-muscle tissue during exercise. Abbreviations: Bdnf, brain-derived neurotrophic factor; Dmnt1, DNA (cytosine-5)-methyltransferase 1; ELOVL, Elongation of very long chain fatty acids protein; FGF21, fibroblast growth factor 21; GLUT4, glucose transporter 4; HSL, hormone-sensitive lipase; KCNQ1, potassium voltage-gated channel subfamily $Q$ member 1; NAFLD, non-alcoholic fatty liver disease; TCFL7L2, Transcription Factor 7-Like 2.

DNA methylation on human subcutaneous adipose tissue from 23 healthy men with low physical activity levels, before and after six months of physical activity intervention, and 31 individuals with or without a family history of type 2 diabetes was analyzed. Here, candidate genes had a higher DNA methylation in adipose in response to exercise, including TCF7L2 and KCNQ1 [141]. In another study using subcutaneous adipose tissue samples, DNA methylation stimulated by acute exercise was much more predominant in trained versus untrained state with modifications after acute exercise for 32 genes pre-training and 6 post-training, especially at adipocyte-specific genes [142].

\subsection{Liver}

MicroRNAs expression, histone modifications, and DNA methylation by modifying DNA accessibility control the activity of genes related to mitochondrial dysfunction, oxidative stress, lipid metabolism, and inflammation. Studies on liver biopsy samples from patients diagnosed with non-alcoholic fatty liver disease (NAFLD) established the modifications in the methylation of genes associated with mitochondrial biogenesis and lipid metabolism [143].

A pattern of fast food and exercise triggers extensive gene alterations, with enrichment of carbohydrate/lipid metabolic pathways and muscle developmental processes. Hypermethylation at a subset of gene promoters was related to inhibition of tissue development and promotion of carcinogenic processes in mouse liver [144].

In a high-fat diet-induced animal model of NAFLD, exercise was capable of decreasing hepatic overexpression of mir-212, which seemed to be related to lipogenesis and NAFLD development, by targeting FGF-21 [145]. In another study, with a high-fat diet in rats, hypoxic physical exercise decreased hepatic levels of mir-378, related to lipid metabolism regulation and triacylglycerol production [146]. 


\subsection{Pancreas}

Swimming routine of physical exercise in high-fat diet-fed fathers led to partial inhibition of pancreatic islet morphology modifications and augmented two pancreatic miRNAs (let7d-5p, 194-5p) in male offspring [147]. This study suggests that the profits of the exercise regime reversed the adverse effects on offspring pancreatic dysfunction of high-fat diet consumption in fathers. Here, mice were randomly assigned to a control diet or a high-fat diet for 9 weeks. After the initial feeding period, males fed the high-fat diet were then allocated to one of the following treatments for a further period of 9 weeks: continuation of a high-fat diet or high-fat diet with exercise intervention. Later the founder males had the opportunity to mate with two normal-weight females for a maximum period of 8 days, and at weaning (day 21 of life) male offspring were separated from their mothers, group-housed independently of founder treatment, and maintained on standard chow [147].

\subsection{Brain}

Skeletal muscle initiates crosstalk with other tissues to produce the liberation of protein hormones and myokines, which could exert autocrine, paracrine, and long-distance endocrine effects. In addition, the enhanced release or uptake of metabolites from, and into, contracting muscle cells, respectively, could likewise play the role of a powerful mediator of tissue interactions, in particular, with regards to the central nervous system [148]. Exercised and control rats have shown an increased level and induction of histone $\mathrm{H} 3$ phosphoacetylation and c-Fos, and the exercised rats exhibited a greater number of dentate granule neurons expressing the histone changes and initial gene generation [149].

Exercise promotes DNA demethylation in brain-derived neurotrophic factor (BDNF) promoter IV and elevates levels of activated methyl-CpG-binding protein 2, as well as BDNF) mRNA and protein in the rat hippocampus. Epigenetic analysis has shown that exercise increases acetylation of histone $\mathrm{H} 3$, and protein assessment showed that exercise increases the ratio of acetylated histone-total for histone $\mathrm{H} 3$ but had no effects on histone H4 levels [136].

In an animal model experiment using the spontaneous senescence-accelerated P8 mice with exercise, the authors reported modifications in genes related to protein acetylation homeostasis (Sirt1, Hdac6) and Hdac3 and Hdac5 gene expression modulation in the hippocampus. Global histone $\mathrm{H} 3$ acetylation scores were diminished in spontaneous senescence-accelerated P8 mouse model mice compared with senescence-accelerated resistant mice $[150,151]$. In similar studies, long-term exercise in rats and mice enhanced the activity of both histone acetyltransferases (HAT) and histone deacetylases (HDAC) in the hippocampus, which showed improved cognitive function [152,153]. Alterations in the hippocampus following traumatic brain injury showed recuperated hippocampusrelated cognitive deficits after running wheel exercise, and both miR-21 and miR-34a were related to the recovery process [154]. Low-capacity runner and high-capacity runner rats were exposed to dietary restrictions. Hippocampus samples have shown that specific binding concerning acetylated histone $\mathrm{H} 3$ and BDNF promoters were increased in both groups [155].

Daily exercise protocols induced an increase in histone $\mathrm{H} 4$ acetylation levels in prefrontal cortices of 21-month-old rats, without any effects in the young adult group [156]. After 1 week of physical activity, histone 3 acetylation was increased in the hippocampus and cerebellum, and that was correlated with augmented BDNF in the hippocampus. DNMTs and histone deacetylases pattern, important genes that impact DNA methylation and histone changes in general, diminished in hippocampus and cerebellum with exercise [157]. The exercise was also able to increase hippocampal H3K9 acetylation levels in aged rats [158]. A single physical exercise routine reduced DNA methyltransferases levels in the hippocampus of young adult rats [159]. In addition, using a forced exercise protocol the authors have found reduced proinflammatory markers and increased histone H4 acetylation levels in hippocampus 20-month-old rats [160]. Similar results have been found in histone hyperacetylation in the frontal cortex from Wistar rats exposed to a daily 
running protocol for 2 weeks [161]. DNA methylation in the hippocampus, cortex, and hypothalamus of exercised rats was increased [162].

Exercise was also shown to enrich memory in aged mice, and there was a positive association between 5-methylcytosine miR-137 levels in the hippocampus and hypothalamus and performance in the object location test [163]. In addition, the exercise-induced memory enhancements are complemented by modifications in the hippocampal miRNA-mRNA regulatory net [164]. Different modalities of exercise developed memory performance in aged rats modifying H3K9ac or H3K4me3 at the c-Fos promoter [165]. In 2019, it was reported that DNA methylation in AgRP neurons regulates voluntary exercise behavior in mice [166]. Recently, the beneficial effects in the brain have shown that those modifications might depend on exercise intensity [167] and a short-term period [168]. Here, some microRNAs are described as novel candidates in the influence of exercise on the brain, such as microRNA-409-5p and microRNA-501-3p [169].

In contrast, no effects were observed in DNA methylation in the hippocampus, cortex, hypothalamus, and periaqueductal gray regions of the brain, although it was related to abnormal Dnmt1 and Bdnf expression in cortex, hypothalamus, and periaqueductal gray [170].

\section{Effects of Metabolism and Its Metabolites on Epigenetic Modifications during Exercise}

The process of muscle contraction during exercise requires ATP consumption, and to maintain adequate contractility, an adequate bioavailability of it is needed. Skeletal muscle responds to the high energy demands of exercise, rapidly metabolizing carbohydrates and fats, mainly, and on certain occasions, amino acids. Depending on the manipulation of the training variables, one metabolism will predominate over another, but generally, through resistance training and high-intensity interval training (HIIT), carbohydrate metabolism predominates, and during endurance training at the moderate intensity the fat consumption. Both resistance and endurance training have a great impact on energy production, and consequently, on the generation of metabolites that can epigenetically affect various tissues and organs. As the existence of scientific evidence in this regard in humans is very scarce, most of the studies that will be mentioned are carried out in vitro and experimental animals. When there is a predominance of glycolysis, high amounts of serine are generated, which has been shown to increase methylation in skeletal muscle through recycling of homocysteine to methionine, exerting greater bioavailability to the precursor for de novo methylation. Although it cannot be extrapolated to human skeletal muscle, it has been shown that, in murine model heart muscle, glycolysis regulates a key enzyme for serine resynthesis [171].

As we previously described, lactate is another metabolite with key functions, which increases with the intensity of exercise. Both in vivo and in vitro studies have shown that lactate inhibits HDAC through the histone complex 4, acetylating histone marks, and increasing gene expression in the abovementioned modification called lactylation [112]. Recently, by using stable carbon isotopes, lactyl groups have been identified and it seems to promote epigenetic modifications through lysine residues. Furthermore, lysine lactylation appears to occur in the promoter regions of the encoded genes and is positively correlated with the expression of these transcripts $[113,172]$. Therefore, lactate is a bioactive metabolite that acts at the systemic level, triggers epigenetic mechanisms of action not only in skeletal muscle, but could also alter the epigenetics of other tissues and organs. Indeed, rats that were treated with lactate were more resilient to stress due to the restoration of HDAC2 and HDAC3 levels in the hippocampus [173]. The study of the effects of lactate produced by exercise on the different epigenetic modifications requires more research, and it is of vital importance to determine specific doses of physical exercise depending on the profile and the individual.

During moderate-intensity resistance training, the main energy substrate predominating is the use of fatty acids. To use them, lipolysis, the metabolic process from which 
triglycerides are broken down into fatty acids and glycerol, is necessary. Short- or mediumchain fatty acids cross the mitochondrial membrane without the need for any transporter, while long-chain fatty acids require carnitine to enter the mitochondria [174]. Once introduced into the mitochondria, they are used for energy through beta-oxidation. Butyrate, a short-chain fatty acid, has been shown to have an inhibitory effect on HDACs [175], which could prevent and treat diet-induced insulin resistance in mice. In prolonged exercises, acetoacetate is produced by the liver. A minor part of the acetoacetate circulates to the bloodstream, while the majority breaks down into beta-hydroxybutyrate $(\beta-\mathrm{HB})$, which is released to the blood and can interact in other tissues such as skeletal muscle. $\beta-\mathrm{HB}$ is a ketone body that inhibits HDACs [176], including HDAC 1, 3, and 4, which increases histone acetylation, decreases $\alpha$-synuclein toxicity, and prevents dopaminergic neurons from cell death through histone acetylation. Therefore, $\beta-\mathrm{HB}$ might regulate HDACs and modify gene expression through these mechanisms. $\beta$-HB-mediated inhibition of HDACs in mice also increases BDNF expression, reduces the $\mathrm{NAD}^{+} / \mathrm{NADH}$ ratio, and increases ATP, which is narrowly related to adult neurogenesis $[177,178]$. Another study revealed that $\beta$-HB impacts on gene transcription in rat myotubes, up-regulating PGC1 $\alpha, \mathrm{CPT} 1 b$, mitochondrial sirtuins (SIRT3-5), and the mitochondrial anti-oxidative genes SOD2 and catalase [179] indicating a putative impact on muscle metabolism.

The acetyl-CoA metabolite enters the Krebs cycle and produces different chemical reactions that, during the metabolic process, give rise to intermediates that regulate the activity of different enzymes. After an acute exercise session and a chronic training program, intramuscular concentrations of Krebs cycle intermediates such as fumarate, citrate, or succinate are shown to be higher. In particular, ATP citrate synthase produces epigenetic modifications in skeletal muscle through hyperacetylation of K9, 14, and 27, increasing myoD expression, and pathways associated with IGF-1, an important regulator of muscle cell survival, differentiation, and proliferation [180]. Moreover, ATP citrate synthase plays a role in histone modifications, linking differentiation of satellite cells and myoblasts in skeletal muscle. Therefore, resistance training, which is a great stimulator of IGF-1, could be the main training method that triggers epigenetic adaptations through these mechanisms.

Regarding muscle contraction, calcium is an important molecule that is increased and the intracellular levels produce the binding of the $\mathrm{Ca}^{2+}$ ion with calmodulin, forming the CaMK-II complex [181]. Consequently, nuclear activation of CaMK-II phosphorylates $\mathrm{MeCP}$, a protein that produces epigenetic changes through chromatin remodeling. Thus, the increase in CaMK-IV produces hypomethylation of DNA in skeletal muscle after 7 weeks of resistance training [81], establishing an important epigenetic role for a number of largely unstudied genes in muscle hypertrophy/memory.

Finally, skeletal muscle is an endocrine organ that secretes a large number of cytokines and different types of proteins, in response to muscle contraction, which has an impact not only on the muscle itself but also on a systemic level. Thus, it releases other peptides and nucleic acids called exerkines into the bloodstream. Exerkines can be released from extracellular vesicles known as exosomes, which contain nucleic acids, mRNA, miRNA, and mitochondrial deoxyribonucleic acids [182]. Thus, recent studies have identified that skeletal muscle, through muscle contraction, is also capable of releasing extracellular vesicles into the bloodstream, capable of producing changes in other tissues through miRNAs. These vesicles, together, increase or decrease the expression of certain genes, in addition to other series of post-transcriptional modifications [183]. In particular, resistance exercise causes a higher muscle tissue release of extracellular vesicles containing miR-1, which is captured by white adipose tissue, consequently stimulating lipolysis of this adipose tissue. Therefore, through the endocrine capacity of skeletal muscle through the release of different types of proteins, epigenetic changes can also occur due to the generation of miRNAs that, ultimately, favor metabolic adaptations for the treatment of diseases. 


\section{Conclusions and Future Perspectives}

Physical exercise and exercise trigger numerous changes and metabolic adaptations in the organism, resulting in an improvement in functional capacity and health, as well as decreasing the risk of developing metabolic or chronic diseases. In particular, a complex network of molecular mechanisms is activated in skeletal muscle, and the contraction releases active proteins, nucleic acids, and metabolites that may be involved in the inter-organ communication that is likely to mediate many of the effects of exercise. Indeed, some of these metabolites may serve as a substrate to allow epigenetic modifications in skeletal muscle, enabling transcriptional changes to key signaling pathways, and ultimately, muscle adaptation and remodeling. The interaction between these epigenetic modifications and the complexity of physiology is intricate and this should be further researched in order to elucidate all the signal events occurring during exercise in skeletal muscle. Hence, exercise is a powerful tool for altering gene expression profiles in skeletal muscle by epigenetic modifications. DNA hypomethylation and histone hyperacetylation, both in key exerciseresponsive genes in skeletal muscle are the most established mechanism of adaptation to exercise. However, other modifications also ensue in histones and epigenetic changes involving microRNAs. Furthermore, the impact of exercise on epigenetic modifications seems to depend on the type, intensity, and duration of exercise. In this context, resistance and endurance exercise differ in the transcriptional regulation in skeletal muscle. In addition, the studies reveal abundant heterogeneity among them in terms of design (e.g., differences between cohorts in sex, age, etc.) and methodology (candidate genes used, type of exercise involved: acute/chronic, resistance/endurance, high/low intensity, training programs of short/long duration); therefore, quantitative analyses of the published literature cannot be performed. Improved understanding of all these interactions would help to optimize the development of novel therapeutic strategies in order to manage metabolic disease through exercise.

Author Contributions: J.P.-D., D.I., Á.T.-M., A.T.B., C.M.A. and F.J.R.-O. participated in the bibliographic search, discussion, and writing of the manuscript. J.P.-D. and F.J.R.-O. designed the work. C.M.A. and F.J.R.-O. revised the manuscript. All authors have read and agreed to the published version of the manuscript.

Funding: This research received no external funding.

Institutional Review Board Statement: Not applicable.

Informed Consent Statement: Not applicable.

Acknowledgments: Julio Plaza-Diaz and Concepción M. Aguilera are part of the "UGR Plan Propio de Investigación 2016" and the "Excellence actions: Unit of Excellence on Exercise and Health (UCEES), University of Granada". Julio Plaza-Diaz is supported by a fellowship to postdoctoral researchers at foreign universities and research centers from the "Fundación Ramón Areces", Madrid, Spain. Francisco Javier Ruiz-Ojeda is supported by a fellowship from Spanish Government "Agencia Estatal de Investigación-Juan de la Cierva-Incorporación" program (IJC2020-042739-I). Álvaro TorresMartos is supported by the Project "Transductores Moleculares del Ejercicio Físico y la Activación del Tejido Adiposo Pardo: en Busca de Nuevas Dianas Terapéuticas en la Comunicación Intercelular" funded by "Consejería de Economía, Conocimiento, Empresas y Universidad (PY18-4455), Junta de Andalucía", Spain.

Conflicts of Interest: The authors declare no conflict of interest. 


\section{References}

1. Latorre-Román, P.Á.; Guzmán-Guzmán, I.P.; Delgado-Floody, P.; Herrador Sanchez, J.; Aragón-Vela, J.; García Pinillos, F.; Párraga Montilla, J.A. Protective role of physical activity patterns prior to COVID-19 confinement with the severity/duration of respiratory pathologies consistent with COVID-19 symptoms in Spanish populations. Res. Sports Med. 2021, 1-12. [CrossRef]

2. Caspersen, C.J.; Powell, K.E.; Christenson, G.M. Physical activity, exercise, and physical fitness: Definitions and distinctions for health-related research. Public Health Rep. 1985, 100, 126.

3. Aragon-Vela, J.; Solis-Urra, P.; Ruiz-Ojeda, F.J.; Alvarez-Mercado, A.I.; Olivares-Arancibia, J.; Plaza-Diaz, J. Impact of Exercise on Gut Microbiota in Obesity. Nutrients 2021, 13, 3999. [CrossRef]

4. Cox, C.E. Role of Physical Activity for Weight Loss and Weight Maintenance. Diabetes Spectr. 2017, 30, 157-160. [CrossRef]

5. Noakes, T.; Spedding, M. Olympics: Run for your life. Nature 2012, 487, 295-296. [CrossRef] [PubMed]

6. Booth, F.W.; Roberts, C.K.; Laye, M.J. Lack of exercise is a major cause of chronic diseases. Compr. Physiol. 2012, 2, $1143-1211$. [CrossRef]

7. Hawley, J.A.; Hargreaves, M.; Joyner, M.J.; Zierath, J.R. Integrative biology of exercise. Cell 2014, 159, 738-749. [CrossRef]

8. Coffey, V.G.; Hawley, J.A. The molecular bases of training adaptation. Sports Med. 2007, 37, 737-763. [CrossRef]

9. Baar, K. Training for endurance and strength: Lessons from cell signaling. Med. Sci. Sports Exerc. 2006, 38, 1939-1944. [CrossRef]

10. Karp, J.R. Muscle fiber types and training. Strength Cond. J. 2001, 23, 21. [CrossRef]

11. Hughes, D.C.; Ellefsen, S.; Baar, K. Adaptations to Endurance and Strength Training. Cold Spring Harb. Perspect. Med. 2018, 8, a029769. [CrossRef] [PubMed]

12. Rivera-Brown, A.M.; Frontera, W.R. Principles of exercise physiology: Responses to acute exercise and long-term adaptations to training. PmEr 2012, 4, 797-804. [CrossRef]

13. Hawley, J.A. Molecular responses to strength and endurance training: Are they incompatible? Appl. Physiol. Nutr. Metab. 2009, 34, 355-361. [CrossRef]

14. Hoffman, N.J.; Parker, B.L.; Chaudhuri, R.; Fisher-Wellman, K.H.; Kleinert, M.; Humphrey, S.J.; Yang, P.; Holliday, M.; Trefely, S.; Fazakerley, D.J.; et al. Global Phosphoproteomic Analysis of Human Skeletal Muscle Reveals a Network of Exercise-Regulated Kinases and AMPK Substrates. Cell Metab. 2015, 22, 922-935. [CrossRef] [PubMed]

15. Gowans, G.J.; Hawley, S.A.; Ross, F.A.; Hardie, D.G. AMP is a true physiological regulator of AMP-activated protein kinase by both allosteric activation and enhancing net phosphorylation. Cell Metab. 2013, 18, 556-566. [CrossRef] [PubMed]

16. Hardie, D.G. AMP-Ksensing energy while talking to other signaling pathways. Cell Metab. 2014, 20, 939-952. [CrossRef]

17. Viollet, B. The Energy Sensor AMPK: Adaptations to Exercise, Nutritional and Hormonal Signals. In Hormones, Metabolism and the Benefits of Exercise; Spiegelman, B., Ed.; Springer Nature: Cham, Switzerland, 2017; pp. 13-24. [CrossRef]

18. Chin, E.R. Intracellular $\mathrm{Ca}^{2+}$ signaling in skeletal muscle: Decoding a complex message. Exerc. Sport Sci. Rev. 2010, 38, 76-85. [CrossRef]

19. McKinsey, T.A.; Zhang, C.L.; Olson, E.N. Activation of the myocyte enhancer factor-2 transcription factor by calcium/calmodulindependent protein kinase-stimulated binding of 14-3-3 to histone deacetylase 5. Proc. Natl. Acad. Sci. USA 2000, 97, 14400-14405. [CrossRef]

20. Bird, A. DNA methylation patterns and epigenetic memory. Genes Dev. 2002, 16, 6-21. [CrossRef]

21. Rakyan, V.K.; Down, T.A.; Maslau, S.; Andrew, T.; Yang, T.P.; Beyan, H.; Whittaker, P.; McCann, O.T.; Finer, S.; Valdes, A.M.; et al. Human aging-associated DNA hypermethylation occurs preferentially at bivalent chromatin domains. Genome Res. 2010, 20, 434-439. [CrossRef] [PubMed]

22. Seaborne, R.A.; Sharples, A.P. The Interplay Between Exercise Metabolism, Epigenetics, and Skeletal Muscle Remodeling. Exerc. Sport Sci. Rev. 2020, 48, 188-200. [CrossRef] [PubMed]

23. McGee, S.L.; Hargreaves, M. Epigenetics and Exercise. Trends Endocrinol. Metab. 2019, 30, 636-645. [CrossRef] [PubMed]

24. Stephens, K.E.; Miaskowski, C.A.; Levine, J.D.; Pullinger, C.R.; Aouizerat, B.E. Epigenetic regulation and measurement of epigenetic changes. Biol. Res. Nurs. 2013, 15, 373-381. [CrossRef]

25. Gibney, E.R.; Nolan, C.M. Epigenetics and gene expression. Heredity 2010, 105, 4-13. [CrossRef]

26. Handy, D.E.; Castro, R.; Loscalzo, J. Epigenetic modifications: Basic mechanisms and role in cardiovascular disease. Circulation 2011, 123, 2145-2156. [CrossRef] [PubMed]

27. Michalak, E.M.; Burr, M.L.; Bannister, A.J.; Dawson, M.A. The roles of DNA, RNA and histone methylation in ageing and cancer. Nat. Rev. Mol. Cell Biol. 2019, 20, 573-589. [CrossRef] [PubMed]

28. Tiffon, C. The Impact of Nutrition and Environmental Epigenetics on Human Health and Disease. Int. J. Mol. Sci. 2018, 19, 3425. [CrossRef]

29. van Dongen, J.; Nivard, M.G.; Willemsen, G.; Hottenga, J.J.; Helmer, Q.; Dolan, C.V.; Ehli, E.A.; Davies, G.E.; van Iterson, M.; Breeze, C.E.; et al. Genetic and environmental influences interact with age and sex in shaping the human methylome. Nat. Commun. 2016, 7, 11115. [CrossRef]

30. Widmann, M.; Niess, A.M.; Munz, B. Physical Exercise and Epigenetic Modifications in Skeletal Muscle. Sports Med. 2019, 49, 509-523. [CrossRef] [PubMed]

31. Jacques, M.; Hiam, D.; Craig, J.; Barres, R.; Eynon, N.; Voisin, S. Epigenetic changes in healthy human skeletal muscle following exercise-A systematic review. Epigenetics 2019, 14, 633-648. [CrossRef] 
32. Rasmussen, M.; Zierath, J.R.; Barres, R. Dynamic epigenetic responses to muscle contraction. Drug Discov. Today 2014, 19, 1010-1014. [CrossRef]

33. Santos, J.M.; Tewari, S.; Benite-Ribeiro, S.A. The effect of exercise on epigenetic modifications of PGC1: The impact on type 2 diabetes. Med. Hypotheses 2014, 82, 748-753. [CrossRef] [PubMed]

34. Listrat, A.; Lebret, B.; Louveau, I.; Astruc, T.; Bonnet, M.; Lefaucheur, L.; Picard, B.; Bugeon, J. How Muscle Structure and Composition Influence Meat and Flesh Quality. Sci. World J. 2016, 2016, 3182746. [CrossRef]

35. Atherton, P.J.; Smith, K. Muscle protein synthesis in response to nutrition and exercise. J. Physiol. 2012, 590, 1049-1057. [CrossRef] [PubMed]

36. Frontera, W.R.; Ochala, J. Skeletal muscle: A brief review of structure and function. Calcif. Tissue Int. 2015, 96, 183-195. [CrossRef] [PubMed]

37. Bottinelli, R.; Reggiani, C. Human skeletal muscle fibres: Molecular and functional diversity. Prog. Biophys. Mol. Biol. 2000, 73, 195-262. [CrossRef]

38. Taylor, J.L.; Amann, M.; Duchateau, J.; Meeusen, R.; Rice, C.L. Neural Contributions to Muscle Fatigue: From the Brain to the Muscle and Back Again. Med. Sci. Sports Exerc. 2016, 48, 2294-2306. [CrossRef] [PubMed]

39. Joyner, M.J.; Casey, D.P. Regulation of increased blood flow (hyperemia) to muscles during exercise: A hierarchy of competing physiological needs. Physiol. Rev. 2015, 95, 549-601. [CrossRef]

40. Radak, Z.; Zhao, Z.; Koltai, E.; Ohno, H.; Atalay, M. Oxygen consumption and usage during physical exercise: The balance between oxidative stress and ROS-dependent adaptive signaling. Antioxid. Redox Signal. 2013, 18, 1208-1246. [CrossRef]

41. McGee, S.L.; Hargreaves, M. Exercise adaptations: Molecular mechanisms and potential targets for therapeutic benefit. Nat. Rev. Endocrinol. 2020, 16, 495-505. [CrossRef]

42. Aon, M.A.; Bhatt, N.; Cortassa, S.C. Mitochondrial and cellular mechanisms for managing lipid excess. Front. Physiol. 2014, 5, 282. [CrossRef] [PubMed]

43. Bazgir, B.; Fathi, R.; Rezazadeh Valojerdi, M.; Mozdziak, P.; Asgari, A. Satellite Cells Contribution to Exercise Mediated Muscle Hypertrophy and Repair. Cell J. 2017, 18, 473-484. [CrossRef]

44. Roberts, M.D.; Haun, C.T.; Vann, C.G.; Osburn, S.C.; Young, K.C. Sarcoplasmic Hypertrophy in Skeletal Muscle: A Scientific "Unicorn" or Resistance Training Adaptation? Front. Physiol. 2020, 11, 816. [CrossRef] [PubMed]

45. Krzysztofik, M.; Wilk, M.; Wojdala, G.; Golas, A. Maximizing Muscle Hypertrophy: A Systematic Review of Advanced Resistance Training Techniques and Methods. Int. J. Environ. Res. Public Health 2019, 16, 4897. [CrossRef] [PubMed]

46. Mangine, G.T.; Hoffman, J.R.; Gonzalez, A.M.; Townsend, J.R.; Wells, A.J.; Jajtner, A.R.; Beyer, K.S.; Boone, C.H.; Miramonti, A.A.; Wang, R.; et al. The effect of training volume and intensity on improvements in muscular strength and size in resistance-trained men. Physiol. Rep. 2015, 3, e12472. [CrossRef]

47. de Freitas, M.C.; Gerosa-Neto, J.; Zanchi, N.E.; Lira, F.S.; Rossi, F.E. Role of metabolic stress for enhancing muscle adaptations: Practical applications. World J. Methodol. 2017, 7, 46-54. [CrossRef]

48. Phillips, B.E.; Williams, J.P.; Gustafsson, T.; Bouchard, C.; Rankinen, T.; Knudsen, S.; Smith, K.; Timmons, J.A.; Atherton, P.J. Molecular networks of human muscle adaptation to exercise and age. PLoS Genet. 2013, 9, e1003389. [CrossRef]

49. McGlory, C.; Devries, M.C.; Phillips, S.M. Skeletal muscle and resistance exercise training; the role of protein synthesis in recovery and remodeling. J. Appl. Physiol. 2017, 122, 541-548. [CrossRef]

50. Korthuis, R.J. Exercise hyperemia and regulation of tissue oxygenation during muscular activity. In Skeletal Muscle Circulation; Morgan \& Claypool Life Sciences; Morgan \& Claypool: San Rafael, CA, USA, 2011.

51. Egan, B.; Zierath, J.R. Exercise metabolism and the molecular regulation of skeletal muscle adaptation. Cell Metab. 2013, 17, 162-184. [CrossRef]

52. Moore, L.D.; Le, T.; Fan, G. DNA methylation and its basic function. Neuropsychopharmacology 2013, 38, 23-38. [CrossRef]

53. Li, E.; Zhang, Y. DNA methylation in mammals. Cold Spring Harb. Perspect. Biol. 2014, 6, a019133. [CrossRef]

54. Feng, J.; Chang, H.; Li, E.; Fan, G. Dynamic expression of de novo DNA methyltransferases Dnmt3a and Dnmt3b in the central nervous system. J. Neurosci. Res. 2005, 79, 734-746. [CrossRef] [PubMed]

55. Goto, K.; Numata, M.; Komura, J.I.; Ono, T.; Bestor, T.H.; Kondo, H. Expression of DNA methyltransferase gene in mature and immature neurons as well as proliferating cells in mice. Differentiation 1994, 56, 39-44. [CrossRef]

56. Saxonov, S.; Berg, P.; Brutlag, D.L. A genome-wide analysis of CpG dinucleotides in the human genome distinguishes two distinct classes of promoters. Proc. Natl. Acad. Sci. USA 2006, 103, 1412-1417. [CrossRef]

57. Illingworth, R.S.; Gruenewald-Schneider, U.; Webb, S.; Kerr, A.R.; James, K.D.; Turner, D.J.; Smith, C.; Harrison, D.J.; Andrews, R.; Bird, A.P. Orphan CpG islands identify numerous conserved promoters in the mammalian genome. PLoS Genet. 2010, 6, e1001134. [CrossRef] [PubMed]

58. Hervouet, E.; Peixoto, P.; Delage-Mourroux, R.; Boyer-Guittaut, M.; Cartron, P.F. Specific or not specific recruitment of DNMTs for DNA methylation, an epigenetic dilemma. Clin. Epigenetics 2018, 10, 17. [CrossRef] [PubMed]

59. Watt, F.; Molloy, P.L. Cytosine methylation prevents binding to DNA of a HeLa cell transcription factor required for optimal expression of the adenovirus major late promoter. Genes Dev. 1988, 2, 1136-1143. [CrossRef]

60. Barres, R.; Yan, J.; Egan, B.; Treebak, J.T.; Rasmussen, M.; Fritz, T.; Caidahl, K.; Krook, A.; O'Gorman, D.J.; Zierath, J.R. Acute exercise remodels promoter methylation in human skeletal muscle. Cell Metab. 2012, 15, 405-411. [CrossRef] [PubMed] 
61. King-Himmelreich, T.S.; Schramm, S.; Wolters, M.C.; Schmetzer, J.; Moser, C.V.; Knothe, C.; Resch, E.; Peil, J.; Geisslinger, G.; Niederberger, E. The impact of endurance exercise on global and AMPK gene-specific DNA methylation. Biochem. Biophys. Res. Commun. 2016, 474, 284-290. [CrossRef]

62. Baker, J.S.; McCormick, M.C.; Robergs, R.A. Interaction among Skeletal Muscle Metabolic Energy Systems during Intense Exercise. J. Nutr. Metab. 2010, 2010, 905612. [CrossRef]

63. Kietzmann, T.; Petry, A.; Shvetsova, A.; Gerhold, J.M.; Gorlach, A. The epigenetic landscape related to reactive oxygen species formation in the cardiovascular system. Br. J. Pharmacol. 2017, 174, 1533-1554. [CrossRef] [PubMed]

64. Petracci, I.; Gabbianelli, R.; Bordoni, L. The Role of Nutri(epi)genomics in Achieving the Body's Full Potential in Physical Activity. Antioxidants 2020, 9, 498. [CrossRef] [PubMed]

65. Fischer, C.P. Interleukin-6 in acute exercise and training: What is the biological relevance? Exerc. Immunol. Rev. 2006, 12, 6-33.

66. Bagley, J.R.; Burghardt, K.J.; McManus, R.; Howlett, B.; Costa, P.B.; Coburn, J.W.; Arevalo, J.A.; Malek, M.H.; Galpin, A.J. Epigenetic Responses to Acute Resistance Exercise in Trained vs. Sedentary Men. J. Strength Cond. Res. 2020, 34, 1574-1580. [CrossRef]

67. Voisin, S.; Eynon, N.; Yan, X.; Bishop, D.J. Exercise training and DNA methylation in humans. Acta Physiol. 2015, 213, 39-59. [CrossRef] [PubMed]

68. Maasar, M.F.; Turner, D.C.; Gorski, P.P.; Seaborne, R.A.; Strauss, J.A.; Shepherd, S.O.; Cocks, M.; Pillon, N.J.; Zierath, J.R.; Hulton, A.T.; et al. The Comparative Methylome and Transcriptome after Change of Direction Compared to Straight Line Running Exercise in Human Skeletal Muscle. Front. Physiol. 2021, 12, 619447. [CrossRef] [PubMed]

69. Laker, R.C.; Lillard, T.S.; Okutsu, M.; Zhang, M.; Hoehn, K.L.; Connelly, J.J.; Yan, Z. Exercise prevents maternal high-fat dietinduced hypermethylation of the Pgc-1alpha gene and age-dependent metabolic dysfunction in the offspring. Diabetes 2014, 63, 1605-1611. [CrossRef]

70. Alibegovic, A.C.; Sonne, M.P.; Hojbjerre, L.; Bork-Jensen, J.; Jacobsen, S.; Nilsson, E.; Faerch, K.; Hiscock, N.; Mortensen, B.; Friedrichsen, M.; et al. Insulin resistance induced by physical inactivity is associated with multiple transcriptional changes in skeletal muscle in young men. Am. J. Physiol. Endocrinol. Metab. 2010, 299, E752-E763. [CrossRef]

71. Theilen, N.T.; Kunkel, G.H.; Tyagi, S.C. The Role of Exercise and TFAM in Preventing Skeletal Muscle Atrophy. J. Cell. Physiol. 2017, 232, 2348-2358. [CrossRef]

72. Bajpeyi, S.; Covington, J.D.; Taylor, E.M.; Stewart, L.K.; Galgani, J.E.; Henagan, T.M. Skeletal Muscle PGC1alpha -1 Nucleosome Position and -260 nt DNA Methylation Determine Exercise Response and Prevent Ectopic Lipid Accumulation in Men. Endocrinology 2017, 158, 2190-2199. [CrossRef]

73. Lane, S.C.; Camera, D.M.; Lassiter, D.G.; Areta, J.L.; Bird, S.R.; Yeo, W.K.; Jeacocke, N.A.; Krook, A.; Zierath, J.R.; Burke, L.M.; et al. Effects of sleeping with reduced carbohydrate availability on acute training responses. J. Appl. Physiol. 2015, 119, 643-655. [CrossRef]

74. Nitert, M.D.; Dayeh, T.; Volkov, P.; Elgzyri, T.; Hall, E.; Nilsson, E.; Yang, B.T.; Lang, S.; Parikh, H.; Wessman, Y.; et al. Impact of an exercise intervention on DNA methylation in skeletal muscle from first-degree relatives of patients with type 2 diabetes. Diabetes 2012, 61, 3322-3332. [CrossRef] [PubMed]

75. Robinson, M.M.; Dasari, S.; Konopka, A.R.; Johnson, M.L.; Manjunatha, S.; Esponda, R.R.; Carter, R.E.; Lanza, I.R.; Nair, K.S. Enhanced Protein Translation Underlies Improved Metabolic and Physical Adaptations to Different Exercise Training Modes in Young and Old Humans. Cell Metab. 2017, 25, 581-592. [CrossRef] [PubMed]

76. Lindholm, M.E.; Marabita, F.; Gomez-Cabrero, D.; Rundqvist, H.; Ekstrom, T.J.; Tegner, J.; Sundberg, C.J. An integrative analysis reveals coordinated reprogramming of the epigenome and the transcriptome in human skeletal muscle after training. Epigenetics 2014, 9, 1557-1569. [CrossRef] [PubMed]

77. Turner, D.C.; Gorski, P.P.; Maasar, M.F.; Seaborne, R.A.; Baumert, P.; Brown, A.D.; Kitchen, M.O.; Erskine, R.M.; Dos-Remedios, I.; Voisin, S.; et al. DNA methylation across the genome in aged human skeletal muscle tissue and muscle-derived cells: The role of HOX genes and physical activity. Sci. Rep. 2020, 10, 15360. [CrossRef] [PubMed]

78. Sailani, M.R.; Halling, J.F.; Moller, H.D.; Lee, H.; Plomgaard, P.; Pilegaard, H.; Snyder, M.P.; Regenberg, B. Lifelong physical activity is associated with promoter hypomethylation of genes involved in metabolism, myogenesis, contractile properties and oxidative stress resistance in aged human skeletal muscle. Sci. Rep. 2019, 9, 3272. [CrossRef]

79. Rowlands, D.S.; Page, R.A.; Sukala, W.R.; Giri, M.; Ghimbovschi, S.D.; Hayat, I.; Cheema, B.S.; Lys, I.; Leikis, M.; Sheard, P.W.; et al. Multi-omic integrated networks connect DNA methylation and miRNA with skeletal muscle plasticity to chronic exercise in Type 2 diabetic obesity. Physiol. Genomics 2014, 46, 747-765. [CrossRef]

80. Stephens, N.A.; Brouwers, B.; Eroshkin, A.M.; Yi, F.; Cornnell, H.H.; Meyer, C.; Goodpaster, B.H.; Pratley, R.E.; Smith, S.R.; Sparks, L.M. Exercise Response Variations in Skeletal Muscle PCr Recovery Rate and Insulin Sensitivity Relate to Muscle Epigenomic Profiles in Individuals With Type 2 Diabetes. Diabetes Care 2018, 41, 2245-2254. [CrossRef]

81. Seaborne, R.A.; Strauss, J.; Cocks, M.; Shepherd, S.; O’Brien, T.D.; Someren, K.A.V.; Bell, P.G.; Murgatroyd, C.; Morton, J.P.; Stewart, C.E.; et al. Methylome of human skeletal muscle after acute \& chronic resistance exercise training, detraining \& retraining. Sci. Data 2018, 5, 180213. [CrossRef]

82. Solsona, R.; Sanchez, A.M.J. Exercise and ribosome biogenesis in skeletal muscle hypertrophy: Impact of genetic and epigenetic factors. J. Physiol. 2021, 599, 3803-3805. [CrossRef] 
83. Figueiredo, V.C.; Wen, Y.; Alkner, B.; Fernandez-Gonzalo, R.; Norrbom, J.; Vechetti, I.J., Jr.; Valentino, T.; Mobley, C.B.; Zentner, G.E.; Peterson, C.A.; et al. Genetic and epigenetic regulation of skeletal muscle ribosome biogenesis with exercise. J. Physiol. 2021, 599, 3363-3384. [CrossRef]

84. Sanchez, A.M.; Candau, R.; Bernardi, H. Recent Data on Cellular Component Turnover: Focus on Adaptations to Physical Exercise. Cells 2019, 8, 542. [CrossRef]

85. Ruple, B.A.; Godwin, J.S.; Mesquita, P.H.C.; Osburn, S.C.; Vann, C.G.; Lamb, D.A.; Sexton, C.L.; Candow, D.G.; Forbes, S.C.; Fruge, A.D.; et al. Resistance training rejuvenates the mitochondrial methylome in aged human skeletal muscle. FASEB J. 2021, 35, e21864. [CrossRef] [PubMed]

86. Hooper, J.E.; Scott, M.P. Communicating with Hedgehogs. Nat. Rev. Mol. Cell Biol. 2005, 6, 306-317. [CrossRef] [PubMed]

87. Chiang, C.; Litingtung, Y.; Lee, E.; Young, K.E.; Corden, J.L.; Westphal, H.; Beachy, P.A. Cyclopia and defective axial patterning in mice lacking Sonic hedgehog gene function. Nature 1996, 383, 407-413. [CrossRef]

88. Pepinsky, R.B.; Zeng, C.; Wen, D.; Rayhorn, P.; Baker, D.P.; Williams, K.P.; Bixler, S.A.; Ambrose, C.M.; Garber, E.A.; Miatkowski, K.; et al. Identification of a palmitic acid-modified form of human Sonic hedgehog. J. Biol. Chem. 1998, 273, 14037-14045. [CrossRef] [PubMed]

89. Roessler, E.; Belloni, E.; Gaudenz, K.; Jay, P.; Berta, P.; Scherer, S.W.; Tsui, L.C.; Muenke, M. Mutations in the human Sonic Hedgehog gene cause holoprosencephaly. Nat. Genet. 1996, 14, 357-360. [CrossRef]

90. Palma, V.; Ruiz i Altaba, A. Hedgehog-GLI signaling regulates the behavior of cells with stem cell properties in the developing neocortex. Development 2004, 131, 337-345. [CrossRef] [PubMed]

91. Nusslein-Volhard, C.; Wieschaus, E. Mutations affecting segment number and polarity in Drosophila. Nature 1980, $287,795-801$. [CrossRef] [PubMed]

92. Ingham, P.W.; McMahon, A.P. Hedgehog signaling in animal development: Paradigms and principles. Genes Dev. 2001, 15, 3059-3087. [CrossRef]

93. Torroja, C.; Gorfinkiel, N.; Guerrero, I. Mechanisms of Hedgehog gradient formation and interpretation. J. Neurobiol. 2005, 64, 334-356. [CrossRef] [PubMed]

94. Williams, K.; Carrasquilla, G.D.; Ingerslev, L.R.; Hochreuter, M.Y.; Hansson, S.; Pillon, N.J.; Donkin, I.; Versteyhe, S.; Zierath, J.R.; Kilpelainen, T.O.; et al. Epigenetic rewiring of skeletal muscle enhancers after exercise training supports a role in whole-body function and human health. Mol. Metab. 2021, 53, 101290. [CrossRef] [PubMed]

95. McGee, S.L.; Fairlie, E.; Garnham, A.P.; Hargreaves, M. Exercise-induced histone modifications in human skeletal muscle. J. Physiol. 2009, 587, 5951-5958. [CrossRef] [PubMed]

96. Yu, M.; Stepto, N.K.; Chibalin, A.V.; Fryer, L.G.; Carling, D.; Krook, A.; Hawley, J.A.; Zierath, J.R. Metabolic and mitogenic signal transduction in human skeletal muscle after intense cycling exercise. J. Physiol. 2003, 546, 327-335. [CrossRef] [PubMed]

97. Barreiro, E.; Sznajder, J.I. Epigenetic regulation of muscle phenotype and adaptation: A potential role in COPD muscle dysfunction. J. Appl. Physiol. 2013, 114, 1263-1272. [CrossRef] [PubMed]

98. Bannister, A.J.; Kouzarides, T. Regulation of chromatin by histone modifications. Cell Res. 2011, 21, 381-395. [CrossRef]

99. Clayton, A.L.; Hebbes, T.R.; Thorne, A.W.; Crane-Robinson, C. Histone acetylation and gene induction in human cells. FEBS Lett. 1993, 336, 23-26. [CrossRef]

100. Pogo, B.G.; Allfrey, V.G.; Mirsky, A.E. RNA synthesis and histone acetylation during the course of gene activation in lymphocytes. Proc. Natl. Acad. Sci. USA 1966, 55, 805-812. [CrossRef]

101. Gorisch, S.M.; Wachsmuth, M.; Toth, K.F.; Lichter, P.; Rippe, K. Histone acetylation increases chromatin accessibility. J. Cell Sci. 2005, 118, 5825-5834. [CrossRef] [PubMed]

102. Venkatesh, S.; Workman, J.L. Histone exchange, chromatin structure and the regulation of transcription. Nat. Rev. Mol. Cell Biol. 2015, 16, 178-189. [CrossRef]

103. Lim, C.; Shimizu, J.; Kawano, F.; Kim, H.J.; Kim, C.K. Adaptive responses of histone modifications to resistance exercise in human skeletal muscle. PLoS ONE 2020, 15, e0231321. [CrossRef]

104. Greer, E.L.; Shi, Y. Histone methylation: A dynamic mark in health, disease and inheritance. Nat. Rev. Genet. 2012, 13, 343-357. [CrossRef]

105. Murray, K. The Occurrence of Epsilon-N-Methyl Lysine in Histones. Biochemistry 1964, 3, 10-15. [CrossRef] [PubMed]

106. Black, J.C.; Van Rechem, C.; Whetstine, J.R. Histone lysine methylation dynamics: Establishment, regulation, and biological impact. Mol. Cell 2012, 48, 491-507. [CrossRef] [PubMed]

107. Zhang, Y.; Sun, Z.; Jia, J.; Du, T.; Zhang, N.; Tang, Y.; Fang, Y.; Fang, D. Overview of Histone Modification. Adv. Exp. Med. Biol. 2021, 1283, 1-16. [CrossRef]

108. North, J.A.; Simon, M.; Ferdinand, M.B.; Shoffner, M.A.; Picking, J.W.; Howard, C.J.; Mooney, A.M.; van Noort, J.; Poirier, M.G.; Ottesen, J.J. Histone H3 phosphorylation near the nucleosome dyad alters chromatin structure. Nucleic Acids Res. 2014, 42, 4922-4933. [CrossRef]

109. Schaffer, B.E.; Levin, R.S.; Hertz, N.T.; Maures, T.J.; Schoof, M.L.; Hollstein, P.E.; Benayoun, B.A.; Banko, M.R.; Shaw, R.J.; Shokat, K.M.; et al. Identification of AMPK Phosphorylation Sites Reveals a Network of Proteins Involved in Cell Invasion and Facilitates Large-Scale Substrate Prediction. Cell Metab. 2015, 22, 907-921. [CrossRef] [PubMed] 
110. Awad, S.; Kunhi, M.; Little, G.H.; Bai, Y.; An, W.; Bers, D.; Kedes, L.; Poizat, C. Nuclear CaMKII enhances histone H3 phosphorylation and remodels chromatin during cardiac hypertrophy. Nucleic Acids Res. 2013, 41, 7656-7672. [CrossRef] [PubMed]

111. Lo, W.S.; Trievel, R.C.; Rojas, J.R.; Duggan, L.; Hsu, J.Y.; Allis, C.D.; Marmorstein, R.; Berger, S.L. Phosphorylation of serine 10 in histone $\mathrm{H} 3$ is functionally linked in vitro and in vivo to Gcn5-mediated acetylation at lysine 14. Mol. Cell 2000, 5, 917-926. [CrossRef]

112. Latham, T.; Mackay, L.; Sproul, D.; Karim, M.; Culley, J.; Harrison, D.J.; Hayward, L.; Langridge-Smith, P.; Gilbert, N.; Ramsahoye, B.H. Lactate, a product of glycolytic metabolism, inhibits histone deacetylase activity and promotes changes in gene expression. Nucleic Acids Res. 2012, 40, 4794-4803. [CrossRef]

113. Liberti, M.V.; Locasale, J.W. Histone Lactylation: A New Role for Glucose Metabolism. Trends Biochem. Sci. 2020, 45, 179-182. [CrossRef]

114. Izzo, L.T.; Wellen, K.E. Histone lactylation links metabolism and gene regulation. Nature 2019, 574, 492-493. [CrossRef] [PubMed]

115. Soci, U.P.R.; Melo, S.F.S.; Gomes, J.L.P.; Silveira, A.C.; Nobrega, C.; de Oliveira, E.M. Exercise Training and Epigenetic Regulation: Multilevel Modification and Regulation of Gene Expression. Adv. Exp. Med. Biol. 2017, 1000, 281-322. [CrossRef] [PubMed]

116. Russell, A.P.; Lamon, S.; Boon, H.; Wada, S.; Guller, I.; Brown, E.L.; Chibalin, A.V.; Zierath, J.R.; Snow, R.J.; Stepto, N.; et al. Regulation of miRNAs in human skeletal muscle following acute endurance exercise and short-term endurance training. J. Physiol. 2013, 591, 4637-4653. [CrossRef] [PubMed]

117. Horak, M.; Novak, J.; Bienertova-Vasku, J. Muscle-specific microRNAs in skeletal muscle development. Dev. Biol. 2016, 410, 1-13. [CrossRef] [PubMed]

118. Mooren, F.C.; Viereck, J.; Kruger, K.; Thum, T. Circulating microRNAs as potential biomarkers of aerobic exercise capacity. Am J. Physiol. Heart Circ. Physiol. 2014, 306, H557-H563. [CrossRef]

119. Keller, P.; Vollaard, N.B.; Gustafsson, T.; Gallagher, I.J.; Sundberg, C.J.; Rankinen, T.; Britton, S.L.; Bouchard, C.; Koch, L.G.; Timmons, J.A. A transcriptional map of the impact of endurance exercise training on skeletal muscle phenotype. J. Appl. Physiol. 2011, 110, 46-59. [CrossRef] [PubMed]

120. Nielsen, S.; Scheele, C.; Yfanti, C.; Akerstrom, T.; Nielsen, A.R.; Pedersen, B.K.; Laye, M.J. Muscle specific microRNAs are regulated by endurance exercise in human skeletal muscle. J. Physiol. 2010, 588, 4029-4037. [CrossRef] [PubMed]

121. Fyfe, J.J.; Bishop, D.J.; Zacharewicz, E.; Russell, A.P.; Stepto, N.K. Concurrent exercise incorporating high-intensity interval or continuous training modulates mTORC1 signaling and microRNA expression in human skeletal muscle. Am. J. Physiol. Regul. Integr. Comp. Physiol. 2016, 310, R1297-R1311. [CrossRef]

122. Margolis, L.M.; McClung, H.L.; Murphy, N.E.; Carrigan, C.T.; Pasiakos, S.M. Skeletal Muscle myomiR Are Differentially Expressed by Endurance Exercise Mode and Combined Essential Amino Acid and Carbohydrate Supplementation. Front. Physiol. 2017, 8, 182. [CrossRef]

123. Davidsen, P.K.; Gallagher, I.J.; Hartman, J.W.; Tarnopolsky, M.A.; Dela, F.; Helge, J.W.; Timmons, J.A.; Phillips, S.M. High responders to resistance exercise training demonstrate differential regulation of skeletal muscle microRNA expression. J. Appl. Physiol. 2011, 110, 309-317. [CrossRef]

124. Rivas, D.A.; Lessard, S.J.; Rice, N.P.; Lustgarten, M.S.; So, K.; Goodyear, L.J.; Parnell, L.D.; Fielding, R.A. Diminished skeletal muscle microRNA expression with aging is associated with attenuated muscle plasticity and inhibition of IGF-1 signaling. FASEB J. 2014, 28, 4133-4147. [CrossRef]

125. Ogasawara, R.; Akimoto, T.; Umeno, T.; Sawada, S.; Hamaoka, T.; Fujita, S. MicroRNA expression profiling in skeletal muscle reveals different regulatory patterns in high and low responders to resistance training. Physiol. Genomics 2016, 48, 320-324. [CrossRef] [PubMed]

126. Mueller, M.; Breil, F.A.; Lurman, G.; Klossner, S.; Fluck, M.; Billeter, R.; Dapp, C.; Hoppeler, H. Different molecular and structural adaptations with eccentric and conventional strength training in elderly men and women. Gerontology 2011, 57, 528-538. [CrossRef]

127. Jonkhout, N.; Tran, J.; Smith, M.A.; Schonrock, N.; Mattick, J.S.; Novoa, E.M. The RNA modification landscape in human disease. RNA 2017, 23, 1754-1769. [CrossRef] [PubMed]

128. Diao, L.T.; Xie, S.J.; Lei, H.; Qiu, X.S.; Huang, M.C.; Tao, S.; Hou, Y.R.; Hu, Y.X.; Sun, Y.J.; Zhang, Q.; et al. METTL3 regulates skeletal muscle specific miRNAs at both transcriptional and post-transcriptional levels. Biochem. Biophys. Res. Commun. 2021, 552, 52-58. [CrossRef] [PubMed]

129. Xie, S.J.; Lei, H.; Yang, B.; Diao, L.T.; Liao, J.Y.; He, J.H.; Tao, S.; Hu, Y.X.; Hou, Y.R.; Sun, Y.J.; et al. Dynamic m(6)A mRNA Methylation Reveals the Role of METTL3/14-m(6)A-MNK2-ERK Signaling Axis in Skeletal Muscle Differentiation and Regeneration. Front. Cell Dev. Biol. 2021, 9, 744171. [CrossRef]

130. Li, J.; Pei, Y.; Zhou, R.; Tang, Z.; Yang, Y. Regulation of RNA N(6)-methyladenosine modification and its emerging roles in skeletal muscle development. Int. J. Biol. Sci. 2021, 17, 1682-1692. [CrossRef] [PubMed]

131. Campion, J.; Milagro, F.; Martinez, J.A. Epigenetics and obesity. Prog. Mol. Biol. Transl. Sci. 2010, 94, 291-347. [CrossRef] [PubMed]

132. Choi, S.-W.; Friso, S. Epigenetics: A new bridge between nutrition and health. Adv. Nutr. 2010, 1, 8-16. [CrossRef]

133. McGee, S.L.; Walder, K.R. Exercise and the Skeletal Muscle Epigenome. Cold Spring Harb. Perspect. Med. 2017, 7, a029876. [CrossRef] [PubMed] 
134. Hoene, M.; Weigert, C. The stress response of the liver to physical exercise. Exerc. Immunol. Rev. 2010, 16, 163-183.

135. Chandramohan, Y.; Droste, S.K.; Arthur, J.S.C.; Reul, J.M. The forced swimming-induced behavioural immobility response involves histone $\mathrm{H} 3$ phospho-acetylation and c-Fos induction in dentate gyrus granule neurons via activation of the N-methyl-daspartate/extracellular signal-regulated kinase/mitogen-and stress-activated kinase signalling pathway. Eur. J. Neurosci. 2008, 27, 2701-2713. [PubMed]

136. Gomez-Pinilla, F.; Zhuang, Y.; Feng, J.; Ying, Z.; Fan, G. Exercise impacts brain-derived neurotrophic factor plasticity by engaging mechanisms of epigenetic regulation. Eur. J. Neurosci. 2011, 33, 383-390. [CrossRef] [PubMed]

137. Bae, J.-S.; Oh, A.-R.; Lee, H.-J.; Ahn, Y.-H.; Cha, J.-Y. Hepatic Elovl6 gene expression is regulated by the synergistic action of ChREBP and SREBP-1c. Biochem. Biophys. Res. Commun. 2016, 478, 1060-1066. [CrossRef]

138. Morigny, P.; Houssier, M.; Mairal, A.; Ghilain, C.; Mouisel, E.; Benhamed, F.; Masri, B.; Recazens, E.; Denechaud, P.D.; Tavernier, G.; et al. Interaction between hormone-sensitive lipase and ChREBP in fat cells controls insulin sensitivity. Nat. Metab. 2019, 1, 133-146. [CrossRef]

139. Chadt, A.; Al-Hasani, H. Glucose transporters in adipose tissue, liver, and skeletal muscle in metabolic health and disease. Pflug. Arch. 2020, 472, 1273-1298. [CrossRef]

140. Wheatley, K.E.; Nogueira, L.M.; Perkins, S.N.; Hursting, S.D. Differential effects of calorie restriction and exercise on the adipose transcriptome in diet-induced obese mice. J. Obes. 2011, 2011, 265417. [CrossRef]

141. Ronn, T.; Volkov, P.; Davegardh, C.; Dayeh, T.; Hall, E.; Olsson, A.H.; Nilsson, E.; Tornberg, A.; Dekker Nitert, M.; Eriksson, K.F.; et al. A six months exercise intervention influences the genome-wide DNA methylation pattern in human adipose tissue. PLoS Genet. 2013, 9, e1003572. [CrossRef]

142. Fabre, O.; Ingerslev, L.R.; Garde, C.; Donkin, I.; Simar, D.; Barres, R. Exercise training alters the genomic response to acute exercise in human adipose tissue. Epigenomics 2018, 10, 1033-1050. [CrossRef]

143. Stevanovic, J.; Beleza, J.; Coxito, P.; Ascensao, A.; Magalhaes, J. Physical exercise and liver "fitness": Role of mitochondrial function and epigenetics-related mechanisms in non-alcoholic fatty liver disease. Mol. Metab. 2020, 32, 1-14. [CrossRef] [PubMed]

144. Zhou, D.; Hlady, R.A.; Schafer, M.J.; White, T.A.; Liu, C.; Choi, J.H.; Miller, J.D.; Roberts, L.R.; LeBrasseur, N.K.; Robertson, K.D. High fat diet and exercise lead to a disrupted and pathogenic DNA methylome in mouse liver. Epigenetics 2017, 12, 55-69. [CrossRef] [PubMed]

145. Xiao, J.; Bei, Y.; Liu, J.; Dimitrova-Shumkovska, J.; Kuang, D.; Zhou, Q.; Li, J.; Yang, Y.; Xiang, Y.; Wang, F. miR-212 downregulation contributes to the protective effect of exercise against non-alcoholic fatty liver via targeting FGF-21. J. Cell. Mol. Med. 2016, 20, 204-216. [CrossRef] [PubMed]

146. Lu, Y.-L.; Jing, W.; Feng, L.-S.; Zhang, L.; Xu, J.-F.; You, T.-J.; Zhao, J. Effects of hypoxic exercise training on microRNA expression and lipid metabolism in obese rat livers. J. Zhejiang Univ.-Sci. B 2014, 15, 820-829. [CrossRef] [PubMed]

147. McPherson, N.O.; Lane, M.; Sandeman, L.; Owens, J.A.; Fullston, T. An exercise-only intervention in obese fathers restores glucose and insulin regulation in conjunction with the rescue of pancreatic islet cell morphology and microRNA expression in male offspring. Nutrients 2017, 9, 122. [CrossRef]

148. Delezie, J.; Handschin, C. Endocrine Crosstalk Between Skeletal Muscle and the Brain. Front. Neurol. 2018, 9, 698. [CrossRef]

149. Collins, A.; Hill, L.E.; Chandramohan, Y.; Whitcomb, D.; Droste, S.K.; Reul, J.M. Exercise improves cognitive responses to psychological stress through enhancement of epigenetic mechanisms and gene expression in the dentate gyrus. PLoS ONE 2009, 4, e4330. [CrossRef]

150. Cosin-Tomas, M.; Alvarez-Lopez, M.J.; Sanchez-Roige, S.; Lalanza, J.F.; Bayod, S.; Sanfeliu, C.; Pallas, M.; Escorihuela, R.M.; Kaliman, P. Epigenetic alterations in hippocampus of SAMP8 senescent mice and modulation by voluntary physical exercise. Front. Aging Neurosci. 2014, 6, 51. [CrossRef]

151. Li, X.; Inoue, T.; Hayashi, M.; Maejima, H. Exercise enhances the expression of brain-derived neurotrophic factor in the hippocampus accompanied by epigenetic alterations in senescence-accelerated mice prone 8. Neurosci. Lett. 2019, 706, 176-181. [CrossRef]

152. Maejima, H.; Kanemura, N.; Kokubun, T.; Murata, K.; Takayanagi, K. Exercise enhances cognitive function and neurotrophin expression in the hippocampus accompanied by changes in epigenetic programming in senescence-accelerated mice. Neurosci. Lett. 2018, 665, 67-73. [CrossRef]

153. Maejima, H.; Ninuma, S.; Okuda, A.; Inoue, T.; Hayashi, M. Exercise and low-level GABAA receptor inhibition modulate locomotor activity and the expression of BDNF accompanied by changes in epigenetic regulation in the hippocampus. Neurosci. Lett. 2018, 685, 18-23. [CrossRef]

154. Bao, T.H.; Miao, W.; Han, J.H.; Yin, M.; Yan, Y.; Wang, W.W.; Zhu, Y.H. Spontaneous running wheel improves cognitive functions of mouse associated with miRNA expressional alteration in hippocampus following traumatic brain injury. J. Mol. Neurosci. 2014, 54, 622-629. [CrossRef] [PubMed]

155. Torma, F.; Bori, Z.; Koltai, E.; Felszeghy, K.; Vacz, G.; Koch, L.; Britton, S.; Boldogh, I.; Radak, Z. Eating habits modulate short term memory and epigenetical regulation of brain derived neurotrophic factor in hippocampus of low- and high running capacity rats. Brain Res. Bull. 2014, 107, 54-60. [CrossRef]

156. Cechinel, L.R.; Basso, C.G.; Bertoldi, K.; Schallenberger, B.; de Meireles, L.C.F.; Siqueira, I.R. Treadmill exercise induces age and protocol-dependent epigenetic changes in prefrontal cortex of Wistar rats. Behav. Brain Res. 2016, 313, 82-87. [CrossRef] [PubMed] 
157. Abel, J.L.; Rissman, E.F. Running-induced epigenetic and gene expression changes in the adolescent brain. Int. J. Dev. Neurosci. 2013, 31, 382-390. [CrossRef]

158. de Meireles, L.C.; Bertoldi, K.; Cechinel, L.R.; Schallenberger, B.L.; da Silva, V.K.; Schroder, N.; Siqueira, I.R. Treadmill exercise induces selective changes in hippocampal histone acetylation during the aging process in rats. Neurosci. Lett. 2016, 634, 19-24. [CrossRef] [PubMed]

159. Elsner, V.R.; Lovatel, G.A.; Moyses, F.; Bertoldi, K.; Spindler, C.; Cechinel, L.R.; Muotri, A.R.; Siqueira, I.R. Exercise induces age-dependent changes on epigenetic parameters in rat hippocampus: A preliminary study. Exp. Gerontol. 2013, 48, 136-139. [CrossRef]

160. Lovatel, G.A.; Elsner, V.R.; Bertoldi, K.; Vanzella, C.; Moyses Fdos, S.; Vizuete, A.; Spindler, C.; Cechinel, L.R.; Netto, C.A.; Muotri, A.R.; et al. Treadmill exercise induces age-related changes in aversive memory, neuroinflammatory and epigenetic processes in the rat hippocampus. Neurobiol. Learn. Mem. 2013, 101, 94-102. [CrossRef]

161. Spindler, C.; Cechinel, L.R.; Basso, C.; Moyses, F.; Bertoldi, K.; Roesler, R.; Lovatel, G.A.; Rostirola Elsner, V.; Siqueira, I.R. Treadmill exercise alters histone acetyltransferases and histone deacetylases activities in frontal cortices from wistar rats. Cell. Mol. Neurobiol. 2014, 34, 1097-1101. [CrossRef]

162. Kashimoto, R.K.; Toffoli, L.V.; Manfredo, M.H.F.; Volpini, V.L.; Martins-Pinge, M.C.; Pelosi, G.G.; Gomes, M.V. Physical exercise affects the epigenetic programming of rat brain and modulates the adaptive response evoked by repeated restraint stress. Behav. Brain Res. 2016, 296, 286-289. [CrossRef]

163. Jessop, P.; Toledo-Rodriguez, M. Hippocampal TET1 and TET2 Expression and DNA Hydroxymethylation Are Affected by Physical Exercise in Aged Mice. Front. Cell Dev. Biol. 2018, 6, 45. [CrossRef]

164. Fernandes, J.; Vieira, A.S.; Kramer-Soares, J.C.; Da Silva, E.A.; Lee, K.S.; Lopes-Cendes, I.; Arida, R.M. Hippocampal microRNAmRNA regulatory network is affected by physical exercise. Biochim. Biophys. Acta Gen. Subj. 2018, 1862, 1711-1720. [CrossRef]

165. de Meireles, L.C.F.; Galvao, F., Jr.; Walker, D.M.; Cechinel, L.R.; de Souza Grefenhagen, A.I.; Andrade, G.; Palazzo, R.P.; Lovatel, G.A.; Basso, C.G.; Nestler, E.J.; et al. Exercise Modalities Improve Aversive Memory and Survival Rate in Aged Rats: Role of Hippocampal Epigenetic Modifications. Mol. Neurobiol. 2019, 56, 8408-8419. [CrossRef] [PubMed]

166. MacKay, H.; Scott, C.A.; Duryea, J.D.; Baker, M.S.; Laritsky, E.; Elson, A.E.; Garland, T., Jr.; Fiorotto, M.L.; Chen, R.; Li, Y.; et al. DNA methylation in AgRP neurons regulates voluntary exercise behavior in mice. Nat. Commun. 2019, 10, 5364. [CrossRef] [PubMed]

167. Maejima, H.; Kitahara, M.; Takamatsu, Y.; Mani, H.; Inoue, T. Effects of exercise and pharmacological inhibition of histone deacetylases (HDACs) on epigenetic regulations and gene expressions crucial for neuronal plasticity in the motor cortex. Brain Res. 2021, 1751, 147191. [CrossRef] [PubMed]

168. Tomiga, Y.; Sakai, K.; Ra, S.G.; Kusano, M.; Ito, A.; Uehara, Y.; Takahashi, H.; Kawanaka, K.; Soejima, H.; Higaki, Y. Short-term running exercise alters DNA methylation patterns in neuronal nitric oxide synthase and brain-derived neurotrophic factor genes in the mouse hippocampus and reduces anxiety-like behaviors. FASEB J. 2021, 35, e21767. [CrossRef]

169. Goldberg, M.; Islam, M.R.; Kerimoglu, C.; Lancelin, C.; Gisa, V.; Burkhardt, S.; Kruger, D.M.; Marquardt, T.; Malchow, B.; Schmitt, A.; et al. Exercise as a model to identify microRNAs linked to human cognition: A role for microRNA-409 and microRNA-501. Transl. Psychiatry 2021, 11, 514. [CrossRef]

170. Rodrigues, G.M., Jr.; Toffoli, L.V.; Manfredo, M.H.; Francis-Oliveira, J.; Silva, A.S.; Raquel, H.A.; Martins-Pinge, M.C.; Moreira, E.G.; Fernandes, K.B.; Pelosi, G.G.; et al. Acute stress affects the global DNA methylation profile in rat brain: Modulation by physical exercise. Behav. Brain Res. 2015, 279, 123-128. [CrossRef]

171. Gibb, A.A.; Epstein, P.N.; Uchida, S.; Zheng, Y.; McNally, L.A.; Obal, D.; Katragadda, K.; Trainor, P.; Conklin, D.J.; Brittian, K.R.; et al. Exercise-Induced Changes in Glucose Metabolism Promote Physiological Cardiac Growth. Circulation 2017, 136, $2144-2157$. [CrossRef]

172. Zhang, D.; Tang, Z.; Huang, H.; Zhou, G.; Cui, C.; Weng, Y.; Liu, W.; Kim, S.; Lee, S.; Perez-Neut, M.; et al. Metabolic regulation of gene expression by histone lactylation. Nature 2019, 574, 575-580. [CrossRef]

173. Karnib, N.; El-Ghandour, R.; El Hayek, L.; Nasrallah, P.; Khalifeh, M.; Barmo, N.; Jabre, V.; Ibrahim, P.; Bilen, M.; Stephan, J.S.; et al. Lactate is an antidepressant that mediates resilience to stress by modulating the hippocampal levels and activity of histone deacetylases. Neuropsychopharmacology 2019, 44, 1152-1162. [CrossRef] [PubMed]

174. Longo, N.; Frigeni, M.; Pasquali, M. Carnitine transport and fatty acid oxidation. Biochim. Biophys. Acta 2016, $1863,2422-2435$. [CrossRef]

175. Gao, Z.; Yin, J.; Zhang, J.; Ward, R.E.; Martin, R.J.; Lefevre, M.; Cefalu, W.T.; Ye, J. Butyrate improves insulin sensitivity and increases energy expenditure in mice. Diabetes 2009, 58, 1509-1517. [CrossRef] [PubMed]

176. Newman, J.C.; Verdin, E. Ketone bodies as signaling metabolites. Trends Endocrinol. Metab. 2014, 25, 42-52. [CrossRef] [PubMed]

177. Sleiman, S.F.; Henry, J.; Al-Haddad, R.; El Hayek, L.; Abou Haidar, E.; Stringer, T.; Ulja, D.; Karuppagounder, S.S.; Holson, E.B.; Ratan, R.R.; et al. Exercise promotes the expression of brain derived neurotrophic factor (BDNF) through the action of the ketone body beta-hydroxybutyrate. eLife 2016, 5, e15092. [CrossRef] [PubMed]

178. Marosi, K.; Kim, S.W.; Moehl, K.; Scheibye-Knudsen, M.; Cheng, A.; Cutler, R.; Camandola, S.; Mattson, M.P. 3-Hydroxybutyrate regulates energy metabolism and induces BDNF expression in cerebral cortical neurons. J. Neurochem. 2016, 139, 769-781. [CrossRef] 
179. Chriett, S.; Dabek, A.; Wojtala, M.; Vidal, H.; Balcerczyk, A.; Pirola, L. Prominent action of butyrate over beta-hydroxybutyrate as histone deacetylase inhibitor, transcriptional modulator and anti-inflammatory molecule. Sci. Rep. 2019, 9, 742. [CrossRef]

180. Das, S.; Morvan, F.; Morozzi, G.; Jourde, B.; Minetti, G.C.; Kahle, P.; Rivet, H.; Brebbia, P.; Toussaint, G.; Glass, D.J.; et al. ATP Citrate Lyase Regulates Myofiber Differentiation and Increases Regeneration by Altering Histone Acetylation. Cell Rep. 2017, 21, 3003-3011. [CrossRef]

181. Swulius, M.T.; Waxham, M.N. Ca(2+)/calmodulin-dependent protein kinases. Cell. Mol. Life Sci. 2008, 65, 2637-2657. [CrossRef]

182. Severinsen, M.C.K.; Pedersen, B.K. Muscle-Organ Crosstalk: The Emerging Roles of Myokines. Endocr. Rev. 2020, 41, 594-609. [CrossRef]

183. Vechetti, I.J., Jr.; Valentino, T.; Mobley, C.B.; McCarthy, J.J. The role of extracellular vesicles in skeletal muscle and systematic adaptation to exercise. J. Physiol. 2021, 599, 845-861. [CrossRef] [PubMed] 